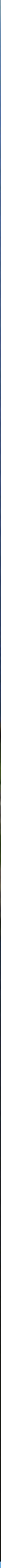

Do assessment thresholds underestimate the mortality impact of wind farms on bird populations?

Buij, R., Schippers, P., Schotman, A., Verboom, J., Van der Jeugd, H., Jongejans, E.

WAGENINGEN

UNIVERSITY \& RESEARCH 



\title{
Do assessment thresholds underestimate the mortality impact of wind farms on bird populations?
}

Buij, R. ${ }^{1}$, Schippers, P. $^{2}$, Schotman, A. ${ }^{1}$, Verboom, J. $^{2}$, Van der Jeugd, H. ${ }^{3}$, Jongejans, E. ${ }^{4}$

\author{
1 Wageningen Environmental Research, Dierecologie, Wageningen, Netherlands \\ 2 Wageningen Environmental Research, Biodiversiteit en Beleid, Wageningen, Netherlands \\ 3 Vogeltrekstation - Dutch Centre for Avian Migration and Demography (NIOO-KNAW), Wageningen, Netherlands \\ 4 Radboud University, Institute of Water and Wetland Research, Departments of Experimental Plant Ecology \& Animal Ecology \\ and Ecophysiology, Nijmegen, Netherlands
}

This research was co-financed by Samenwerkingsverband het Blauwe Hart and the Ministry of Economic Affairs under the program System Earth Management, project Spatial Planning in the Netherlands in the Future; Design of a multifunctionality-proof Spatial Planning instrumentation and legislation.

Wageningen Environmental Research

Wageningen, February 2017

Report 2788

ISSN 1566-7197 
Buij, R., Schippers, P., Schotman, A., Verboom, J., Van der Jeugd, H., Jongejans, E., 2017. Do assessment thresholds underestimate the mortality impact of wind farms on bird populations? Wageningen, Wageningen Environmental Research, Report 2788. 36 pp.; 7 fig.; 7 tab.; 50 ref.

The pdf file is free of charge and can be downloaded at http://dx.doi.org/ 10.18174/406604 or via the website www.wur.nl/environmental-research (scroll down to Publications - Wageningen Environmental Research reports). Wageningen Environmental Research does not deliver printed versions of the Wageningen Environmental Research reports.

(C) 2017 Wageningen Environmental Research (an institute under the auspices of the Stichting Wageningen Research), P.O. Box 47, 6700 AA Wageningen, The Netherlands, T +31 (0)317 4807 00, E info.alterra@wur.nl, www.wur.nl/environmental-research. Wageningen Environmental Research is part of Wageningen University \& Research.

- Acquisition, duplication and transmission of this publication is permitted with clear acknowledgement of the source.

- Acquisition, duplication and transmission is not permitted for commercial purposes and/or monetary gain.

- Acquisition, duplication and transmission is not permitted of any parts of this publication for which the copyrights clearly rest with other parties and/or are reserved.

Wageningen Environmental Research assumes no liability for any losses resulting from the use of the research results or recommendations in this report.

Wageningen Environmental Research Report 2788 | ISSN 1566-7197

Photo cover: https://beeldbank.rws.nl, Rijkswaterstaat 


\section{Contents}

$\begin{array}{ll}\text { Abstract } & 5\end{array}$

$\begin{array}{ll}\text { Samenvatting } & 7\end{array}$

1

$\begin{array}{ll}\text { Introduction } & 9\end{array}$

2

$\begin{array}{ll}\text { Material and Methods } & 11\end{array}$

2.1 The Logistic Growth Model $\quad 11$

2.2 Effect of an increase in mortality on the Population Persistence Index 13

2.3 Assessing the effects of PBR on the Population Persistence Index 15

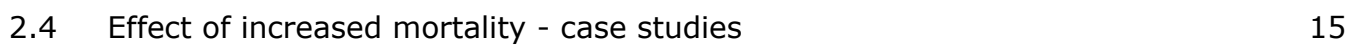

3

Results

3.1 Impact of increased mortality and decreased recruitment on the Population Persistence Index

3.2 Impact of PBR on the Population Persistence Index 19

3.3 Effect of increased mortality on Common Tern and Marsh Harrier 19

4

Discussion

21

$\begin{array}{ll}\text { Conclusions } & 23\end{array}$

$\begin{array}{ll}\text { References } & 24\end{array}$

$\begin{array}{lr}\text { Annex } 1 & 26\end{array}$

$\begin{array}{lr}\text { Annex } 2 & 27\end{array}$

$\begin{array}{lr}\text { Annex } 3 & 28\end{array}$

Annex $4 \quad 32$

$\begin{array}{ll}\text { Annex } 5 & 34\end{array}$ 



\section{Abstract}

The consequences of additional mortality of birds from collisions with a rapidly increasing number of wind turbines are receiving much attention worldwide. Currently, threshold assessments for an acceptable impact on populations are commonly used to evaluate the expected effect of wind turbines on local bird populations. These provide a seemingly clear-cut method for establishing whether damage to the integrity of a population will or will not occur, but questions have recently been raised as to the validity of their use.

In this paper we examine whether two widely used threshold methods for evaluating the impact of extra mortality on bird populations, the $1 \%$ mortality norm and Potential Biological Removal PBR, have general applicability, or whether they should be used more cautiously. The $1 \%$ mortality norm is based upon the assumption that any additional mortality lower than $1 \%$ of the natural mortality has a negligible impact on a population, while the Potential Biological Removal or PBR method is used to estimate the loss of individuals from which a population can still recover. To evaluate the impact of additional mortality resulting from wind turbine collision on bird populations, we model the consequence of an increase in mortality rates on populations assumed to be regulated by logistic growth. We use the logistic growth equation to test how the population persistence of a species may be affected by different levels of additional mortality; and use case studies of existing, declining populations of Common Tern and Marsh Harrier in the Netherlands to determine how the effect of collision mortality operates to influence their population persistence. To examine the impact of additional mortality, we introduce a novel measure, the "Population Persistence Index" or PPI to describe the population persistence and changes therein following increased mortality. The PPI integrates the population growth at various densities - it is determined by the maximum population growth rate at small population size - and the carrying capacity, the population size where recruitment equals mortality.

Our results show that the PPI can be very sensitive to additional mortality, especially in populations in which the mortality approaches the maximum recruitment. We found that a $1 \%$ increase in mortality rates of all post-fledging age classes from wind turbine strike lead to a c. $7-15 \%$ decrease in population persistence for Dutch populations of Marsh Harrier and Common Tern, which should not be considered negligible. Strong effects of additional mortality on PPI are also evident using the PBR. We show that for the PBR, the proportional change in PPI is independent of $r$ and $K$ and depends only on the so-called recovery factor Fr. When this recovery factor $\mathrm{Fr}=1$ (generally used for populations that show sustained growth near carrying capacity), additional mortality results in an $87.5 \%$ reduction of the PPI according to the PBR, and in a $58 \%$ reduction when $\mathrm{Fr}=0.5$ (used for populations with protracted gradual decline). For the PBR of Common Tern a 58\% reduction of the PPI was estimated, and for Marsh Harrier population a $14 \%$ reduction of the PPI at their estimated Fr values, compared to the population not exposed to additional mortality.

We show that the use of the ' $1 \%$ mortality criterion' and the Potential Biological Removal (PBR) method, currently often used in Appropriate Assessments across species in most E.U. countries with rapidly growing wind industry, strongly underestimate the impact of additional mortality on species for which at low population density the recruitment rate is almost equal to the mortality rate. 


\section{Samenvatting}

De gevolgen van de extra sterfte van vogels door botsingen met het snel toenemende aantal windturbines krijgen wereldwijd veel aandacht. Momenteel worden assessments die gebruik maken van een drempelwaarde algemeen gebruikt om het verwachte effect van windturbines op lokale vogelpopulaties te evalueren. Deze bieden een ogenschijnlijk veilige methode om vast te stellen of de staat van instandhouding van een populatie al dan niet negatief beïnvloed wordt, maar onlangs zijn er vragen gerezen over de validiteit van het gebruik van deze drempelwaarden.

In dit artikel gaan we na of de twee veel gebruikte methoden op basis van drempelwaarden om de gevolgen van de extra sterfte op vogelpopulaties te evalueren, de $1 \%$ extra sterfte norm en "Potential Biological Removal" PBR, algemene toepasbaarheid hebben, of dat ze voorzichtiger moeten worden gebruikt. Om het effect van extra sterfte als gevolg van aanvaring met een windturbine op vogelpopulaties te evalueren, modelleren we het gevolg van een toename in de sterfteparameters op de populatie. Hierbij veronderstellen we dat deze gereguleerd wordt door logistische groei. We gebruiken de logistische groeiformule om te testen hoe het voortbestaan van populaties van een soort kan worden beïnvloed door een verschillende mate van additionele sterfte; en om het effect van de extra sterfte te onderzoeken, introduceren we een nieuwe maat, de "Population Persistence Index" (populatie persistentie index) of PPI. Dit is een maat om het voortbestaan van populaties en de veranderingen daarin na verhoogde mortaliteit te beschrijven. De PPI integreert de groei van de populatie bij verschillende dichtheden c.q. populatieomvang en wordt bepaald door het groeipotentieel bij lage dichtheden en de draagkracht van het leefgebied. Draagkracht kan worden opgevat als die grootte van de populatie, waarbij de aanwas en sterfte in evenwicht zijn. De PPI kan zo gezien worden als een buffer tegen uitsterven. Deze buffer is sterk afhankelijk van de grootte van de evenwichtspopulatie. We kijken echter niet naar de PPI zelf, maar naar veranderingen in de PPI.

Onze resultaten tonen aan dat de verandering van PPI zeer gevoelig kan zijn voor extra sterfte, vooral in populaties waarbij de mortaliteit de maximale recruitment (aanwas) benadert. We vonden dat een toename van de mortaliteit met $1 \%$ van alle leeftijdsklassen leidt tot een c. $7-15 \%$ daling van de PPI voor de Nederlandse populatie van Bruine Kiekendief en Visdief. Een afname die volgens ons niet als verwaarloosbaar kan worden beschouwd. We laten zien dat voor het jaarlijkse toegestane verlies van individuen zoals geschat door de PBR, de proportionele verandering in PPI onafhankelijk is van de populatiegroeisnelheid en de populatieomvang en alleen afhankelijk is van de "recovery factor" Fr. Wanneer deze factor $\mathrm{Fr}=1$ (zoals gebruikt voor gezonde, groeiende populaties), leidt extra sterfte ter grootte van de PBR tot een $87.5 \%$ verlaging van de PPI, en wanneer Fr $=0.5$ (voor geleidelijk afnemende populaties) tot een $58 \%$ verlaging. Voor de PBR die gebruikt wordt voor de Visdief wordt een $58 \%$ reductie van de PPI geschat, en voor Bruine Kiekendief een vermindering van $14 \%$ van de PPI bij de gebruikte Fr waarden, ten opzichte van de waarden van een populatie die niet is blootgesteld aan extra mortaliteit.

We tonen aan dat het gebruik van het " $1 \%$ sterfte criterium" en de Potential Biologal Removal (PBR) methode, zoals momenteel vaak voor alle soorten in de meeste E.U. landen gebruikt worden in passende beoordelingen, kan leiden tot ernstige onderschatting van de gevolgen van extra sterfte als gevolg van de snel groeiende windindustrie, vooral bij soorten en populaties waarbij de maximale potentiële aanwas (recruitment) niet veel hoger is dan de natuurlijke sterfte. 


\section{Introduction}

Birds frequently experience additional mortality due to collision with man-made structures, such as wind turbines, communication masts, tall buildings, lighthouses, windows, power lines, and fences (Erickson et al. 2005, Drewitt \& Langston 2008). Despite such collision mortality, which can take substantial tolls on populations in some circumstances (Klem et al. 2004, Drewitt \& Langston 2008), many species maintain high population levels, while other species decline. In general, the consequences of any source of mortality for a bird population depend on its ability to compensate for increases in mortality rates through density-dependent effects (Newton 1998, Liley \& Sutherland 2007). Common species and migrant passerines, which may die in large numbers from collision mortality (e.g. window strikes; Klem 1990) are usually able to respond relatively quickly to population fluctuations (Faanes 1987) and are thus more likely to compensate for losses as a result of collisions. For example, although millions of birds are killed annually by collisions with manmade structures in the U.S., this source of mortality does not seem to have a discernible effect on long-term population trends of migratory landbirds, many of which are passerines (Arnold \& Zink 2011). Indeed, if bird populations are ultimately limited by habitat availability (Rappole \& McDonald 1994), collision mortality will be largely compensatory to natural sources of mortality. In such situations, the loss of any individual may be compensated by the increased fitness of the remainder of individuals in the population through a per capita increase of the average territory quality (e.g. Matthyssen 1990), food availability (e.g. Martin 1987), or a decrease of densitydependent predation pressure (Newton 1993, Sinclair \& Pech 1996). However, ecological traps created by anthropogenic change may limit such compensatory responses to additional mortality (Gilroy \& Sutherland 2007), while increased predation pressure on a smaller population may trigger a decline greater than the cumulative loss from anthropogenic mortality (Sinclair \& Pech 1996, Courchamp et al. 1999). Also, long-lived species, with a low reproductive rate are likely to be more sensitive to changes in adult mortality and less able to compensate by increasing productivity (Sæther \& Bakke 2000), which explains why even low collision rates have contributed to population declines or demographic changes in various long-lived species (e.g. Crivelli et al. 1988, Hunt \& Hunt 2006). Demographic models imply that in the face of this additional mortality, stable populations of such species may only be maintained by immigration, suggesting that wind farms may effectively operate as ecological sinks. For example, the maintenance of a Golden Eagle breeding population in the Altamont Pass wind farm is dependent on immigration (Hunt \& Hunt 2006, Katzner et al. 2016), whereas in other affected raptor populations neither new recruits nor floaters seem to fill up deserted territories, leading to population decline in and around wind farms (Dahl et al. 2012).

Currently, the consequences of additional mortality of birds from collisions with a rapidly increasing number of wind turbines is receiving much attention worldwide (Marques et al. 2014, Schuster et al. 2015). Wind turbine collisions have proven to be a potential hazard to bird population persistence, with potentially important negative, cumulative effects from additional mortality caused by multiple windfarms (Drewitt \& Langston 2006, Carrete et al. 2009, Bellebaum et al. 2013). Long-lived species with relatively low reproductive rates may experience significant collision mortality throughout the annual cycle from wind installations, leading to a decrease in adult survival which has contributed to population declines (Barrios \& Rodriguez 2004, Smallwood \& Thelander 2008, Carrete et al. 2009, Dahl et al. 2012, Martínez-Abrain et al. 2012). Given the reported impacts of wind turbines on bird populations and rapidly expanding wind energy in the E.U., scientific assessments that evaluate the impacts of wind farms on bird populations are under increasing scrutiny (Green et al. 2016). Such assessments are needed to comply with the protection measures and the precautionary principle enshrined in the EU Birds and Habitats Directives (Directive 2009/147/EC and Council Directive 92/43/EEC), which together dictate that populations of naturally occurring wild bird species present in the EU are maintained or restored at a level which will ensure their long-term survival and so-called "favourable conservation status". The latter is central to the EC Habitats Directive and defined as the conservation status when "population dynamics data on the species concerned indicate that it is maintaining itself on a long-term basis as a viable component of its natural habitats, and the natural range of the species is neither being reduced for the foreseeable future, and there is, and will probably continue to be, a sufficiently large habitat to maintain its populations on a long-term basis." Apart from 
general species protection, endangered species are protected in "Special Protection Areas" (SPA's or Natura 2000 sites): key conservation areas for which plans are developed and implemented to maintain specified population targets at the site level. Developments possibly harming these goals, such as wind parks, have to undergo a step-by-step Appropriate Assessment procedure and, where necessary, apply the relevant safeguards for the species and habitat types of community interest. The two Directives also require that Member States protect species of community interest throughout their natural range within the E.U.; thus, any wind farm development must also take account of its potential impacts on species of community interest (those covered by the two Directives) outside SPA's.

The general system of protection in the E.U. prohibits deliberate killing or capture and deliberate disturbance, which according to jurisprudence, is the case if birds are killed as a result of collision with wind turbines (Sateleer 2013). However, Member States may derogate from the provisions on species "to permit, under strictly supervised conditions and on a selective basis, the capture, keeping or other judicious use of certain birds in small numbers" (art. $9(1)(c)$ ). The threshold below which the derogation is automatically considered as meeting the requirements of the notion of 'small numbers' is currently set at $1 \%$ of the overall annual natural mortality in the relevant bio-geographical population. This derogation is the origin of the so-called ' $1 \%$ mortality criterion' as developed by the ORNIS-committee (European Commission 2013). This criterion is said to meet the condition of a negligible effect on the population dynamics of the species concerned because the parameters of population dynamics are seldom known to within less than $1 \%$ point accuracy.

In addition to the $1 \%$ norm, other methods including the Potential Biological Removal (PBR) method are used to define the level of sustainable mortality, or "harvest", from which a population still can recover (Wade 1998), thus identifying a threshold level of additional mortality above which a decline of the affected population to eventual extinction would be likely (Niel \& Lebreton 2005). Potential biological removal provides thresholds of additional mortality that are sensitive to assumptions made about density-dependent effects on the population, which are often unknown. As a result, the PBR threshold for any population is generally multiplied by a so-called 'recovery factor', which is often based upon expert judgement, to provide a safety margin of acceptable additional mortality (Dillingham \& Fletcher 2008).

The thresholds for an acceptable impact commonly used to evaluate the expected effect of wind turbines on local bird populations are convenient to decision makers because they offer an apparently sciencebased and clear-cut method to establish whether damage to the integrity of a designated site will or will not occur. These threshold mortality standards are being used across species in most E.U. countries with rapidly growing wind industry, but questions have recently been raised as to the validity of their use (Green et al. 2016, Horswill et al. 2016). Such questions refer to the uncertainty of the used threshold assessments on populations with different population dynamic characteristics and species vulnerability to additional mortality, as well as the cumulative impacts of wind turbine collision on population developments.

In this paper we investigate how bird species or species groups may be affected by additional mortality and lower recruitment rates (due to higher mortality of younger cohorts in the population) caused by collisions with wind turbines, depending on their population dynamics. We examine whether two widely used threshold methods for evaluating the impact of extra mortality on bird populations, the $1 \%$ mortality norm and PBR, have general applicability, or whether they should be used more cautiously because species differ in traits and vulnerability to additional mortality. To evaluate the impact of additional mortality and reduced recruitment as a result of wind turbine collision on bird populations, we model the consequence of an increase in mortality on a population assumed to be regulated by logistic growth. We use the logistic growth equation to test how the population persistence of a species may be affected by different levels of additional mortality, introducing a novel measure which we term "Population Persistence Index" or PPI to describe relative changes in population persistence. The PPI refers to the strength of a population to withstand increased mortality and integrates both the growth rate at near-zero population size and its carrying capacity. We use the term to describe the population persistence, which relates to its favourable conservation status, and changes therein following increased mortality and decreased recruitment.

Finally, we evaluate the use of mortality thresholds on existing, declining populations of Common Tern and Marsh Harrier in the Netherlands, to determine how the effect of collision operates to influence their population persistence. 


\section{$2 \quad$ Material and Methods}

\subsection{The Logistic Growth Model}

A variety of tools exists for environmental impact assessment on populations. A common tool is population viability analysis (PVA) for assessing the change in population extinction probability or mean time to extinction (Boyce 1992, Beissinger et al. 2002). Population viability analysis, however, tends to be highly species-specific, needs lots of specific parameters and knowledge about species, usually taking into account e.g. demographic stochasticity, environmental stochasticity, and/or genetic stochasticity, and the results are not easily generalizable or transferable to other species. Population viability depends mainly upon the population size, the concept of Minimum Viable Population is often used to describe the population size with a certain, small extinction risk (Flather et al. 2011, Traill et al. 2007). Matrix models are another tool (Caswell 2001). They use state (e.g. age or size)-specific survival and reproduction probabilities and indicate whether populations are projected to increase or decline. Matrix models can be used to predict population resilience, the rate at which populations are expected to return to their equilibrium state after disturbance. However, matrix models are often only suitable for calculating quasiextinction probabilities of declining populations as the density-dependent behaviour of small populations and populations near carrying capacity is usually not taken into account.

We opted to use a generic model, the logistic growth model, and the PPI as outcome, because the PPI combines the population growth rate impact (safety from positive potential growth rate) and the population size impact (safety in numbers), while presenting an alternative measure of population persistence. This approach is closely related to an evaluation of population extinction risk, but more straightforward to assess than a conventional PVA, while the results are generalizable to a variety of species.

We use the logistic growth equation (Verhulst 1977) to test how the population persistence of a species may be affected by different levels of additional mortality. We simply assume a small increase in mortality, above the existing 'natural' mortality, i.e. the mortality from other factors that was already present year-round in the environment of the population. Also, we assume no effect of habitat loss or habitat degeneration as a result of anthropogenic land use, or the potential ecological traps these could generate for birds, possibly leading to suboptimal productivity or survival at low population numbers in seemingly optimal habitat (i.e. when resources are not limiting the population).

We use the term "Population Persistence Index" (hereafter: PPI) to describe the population persistence and changes therein following increased mortality and decreased recruitment. The PPI refers to the area under the logistic growth curve from $\mathrm{N}=0$ to $\mathrm{N}=\mathrm{K}$ (Figure 1). If PPI is large this indicates a relatively stable population with low extinction probability, and vice versa. The PPI thus integrates the population growth at various densities; it is determined by the growth rate at zero population size and the carrying capacity, the population size where recruitment equals mortality (Figure 1). To assess impact of additional mortality we will evaluate the effect of additional mortality on the PPI. The logistic growth model is a widely used model to describe the dynamics of populations. This model is a continuous time model and is described by the differential equation:

$$
\frac{\mathrm{d} N}{\mathrm{~d} t}=r N\left(1-\frac{N}{K}\right)
$$

In which $\mathrm{N}$ is the number of adult females, $\mathrm{r}$ is the relative population growth rate at low densities (where resources are not limiting due to the presence of conspecifics) and $\mathrm{K}$ the carrying capacity of the population, i.e. the equilibrium state where population change is zero - in a simplified environment with constant parameters. When $\mathrm{N}$ approaches zero, the population growth rate $\mathrm{dN} / \mathrm{dt}$ approaches $\mathrm{rN}$ which leads to exponential growth; at $\mathrm{N}$ near carrying capacity $\mathrm{K}$, the population growth rate approaches 0 which leads to a stable population of size $\mathrm{K}$. Between zero and population 
size $\mathrm{K}$, populations tend to grow ( $\mathrm{dN} / \mathrm{dt}>0)$, whereas when population size $>\mathrm{K}$, populations tend to decrease because of limited resources (Figure 1 ).

In order to assess the impact of additional mortality, we modify the logistic growth equation into the simplest equation with explicit mortality and recruitment, assuming the per capita mortality to be density-independent whereas the per capita recruitment is density-dependent. So the resulting density-dependence in the logistic growth equation is assumed to be caused only by densitydependent recruitment. This is plausible because at high densities any limiting resources are more likely to lower the per capita breeding success and juvenile survival than the survival of adults (Newton 1998). This can be summarized by the following equation (Figure 1):

$$
\frac{\mathrm{d} N}{\mathrm{~d} t}=(r+m) N\left(1-\frac{N}{K^{\prime}}\right)-m N
$$

Here $\mathrm{m}$ is the annual mortality of adults and $\mathrm{K}^{\prime}$ the density where the recruitment is zero which can be calculated by solving equation 2 for $\mathrm{dN} / \mathrm{dt}=0$ to assess $\mathrm{K}$ :

$$
K^{\prime}=\frac{K}{\left(1-\frac{m}{(m+r)}\right)}
$$

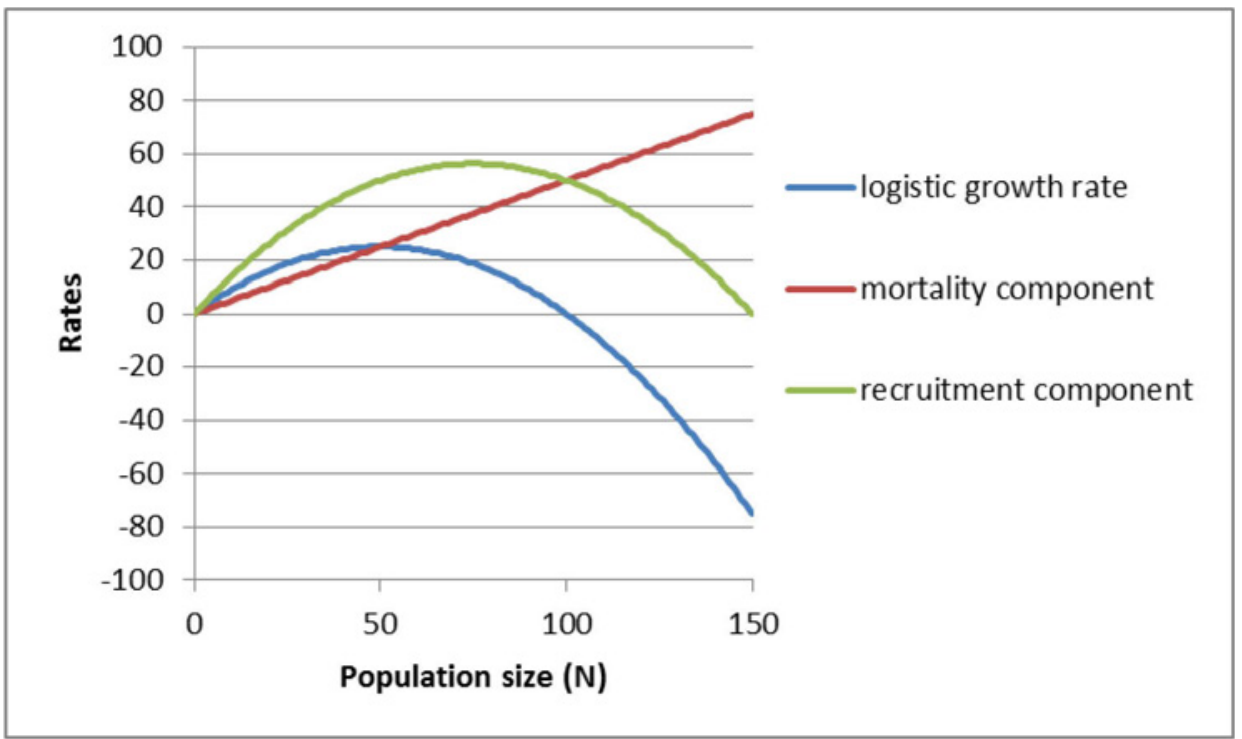

Figure 1 The logistic population growth rate equation (Equation 1) for a population with an equilibrium size $K$ of 100. At low population size, population growth rate increases with population size, then starts to decline as resources become limiting and reaches zero at population size 100. Above this equilibrium, population growth rate becomes negative, i.e. the population declines. The green (recruitment) and red (mortality) lines illustrate the recruitment and mortality components of the model. Mortality is assumed density-independent and increases linearly with population size, whereas recruitment increases at low population size and decreases for large population size. Note that the blue line is derived by subtracting the green and red lines; the equilibrium point where the logistic growth is zero coincides with the point where recruitment equals mortality. While population growth rate can be either positive (increase) or negative (decrease), recruitment and mortality are always positive or zero.

Populations with a positive $r$ and $\mathrm{K}$ persist when confronted with a disturbance that lowers the population size, such as wind turbine collision. Under such conditions, the population growth rate $\mathrm{dN} / \mathrm{dt}$ will increase with a decrease of the population size (Figure 1). The difference between recruitment and mortality is a measure of this persistence: the greater the recruitment than the mortality, i.e. the more space between the lines, the better the recovery potential of the population will be. Although the recruitment and mortality are separated, the model properties follow precisely the widely used logistic growth equation (Figure 2). This feature enables us to easily assess the effect of a mortality increase on the area under the curve, the measure for population persistence PPI. 


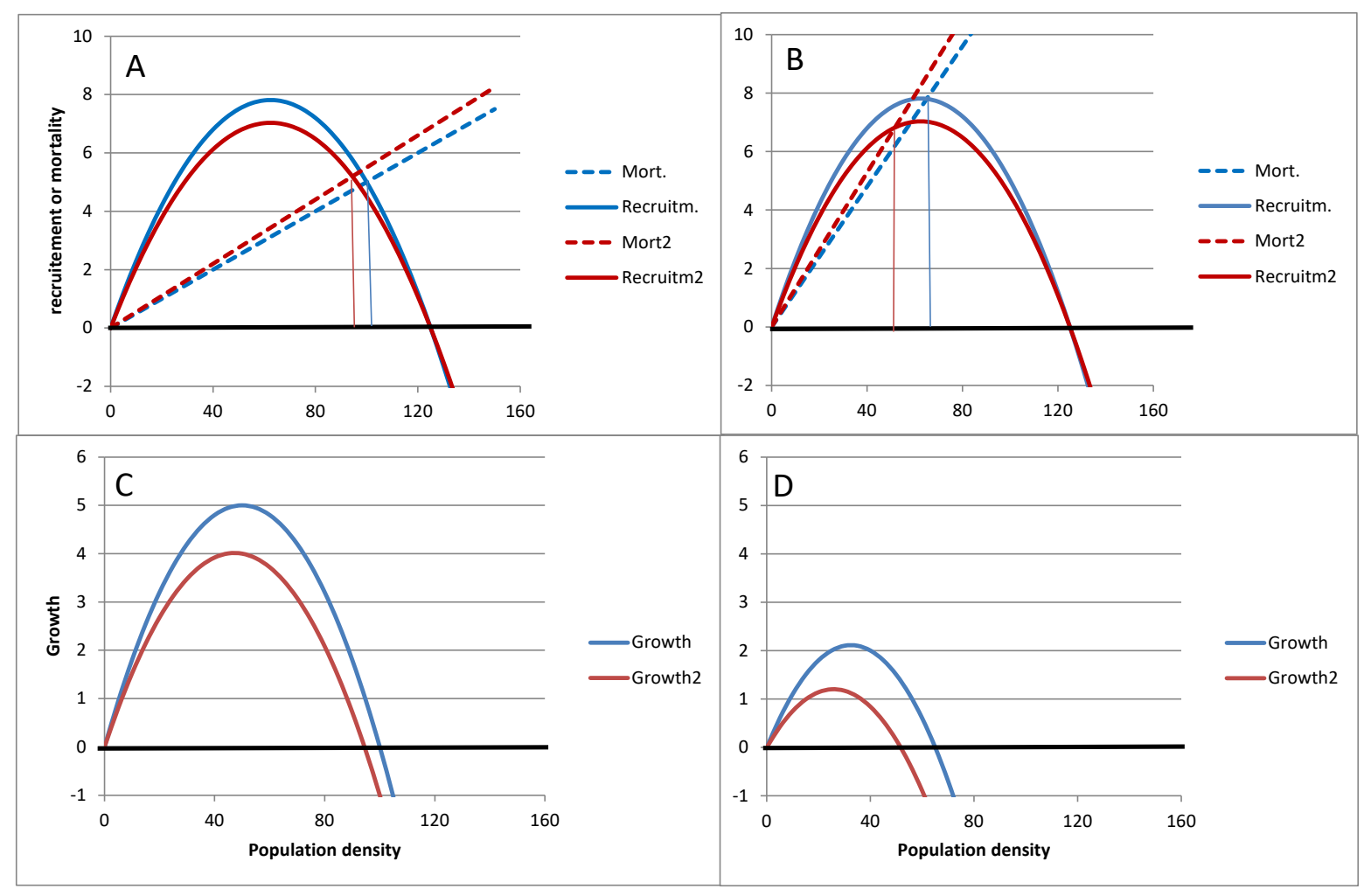

Figure 2 Expanded logistic growth model with density-dependent recruitment. One model illustrates a population with recruitment rates that, at low population densities, are much higher than "natural" mortality rates ( $A, C$; blue lines), the other model a population with the same recruitment rate but with a higher natural mortality rate ( $B, D$; blue lines). We show the effect of a $10 \%$ increase in mortality and a $10 \%$ decrease in recruitment in both situations (red lines), which make the intersection point of mortality and recruitment (the equilibrium population size $K$ ) shift to the left on the $x$-axis (blue horizontal versus red horizontal in $A$ and $B$ ). In the robust population, the area under the growth curve (C), the Population Persistence Index (PPI), declines by $25 \%$ when mortality increases despite the fact that the equilibrium population size $K$ decreases only by $10 \%$. In the second model (D), higher mortality results in a $55 \%$ decline in PPI and a $23 \%$ decline in $K$. Thus the impact on the PPI and equilibrium density of a similar mortality increase is relatively larger in the population already confronted by a higher natural mortality $(B, D)$ compared to the population with lower natural mortality $(A, C)$.

\subsection{Effect of an increase in mortality on the Population Persistence Index}

We first explore the effect of a small mortality increase and recruitment decrease on PPI, the area under the $\mathrm{dN} / \mathrm{dt}$ curve (population growth potential) and a measure of population persistence (Figure 3). We consider this area under the population growth curve to be an indicator for population persistence against extinction in the face of additional mortality, such as resulting from increased wind turbine strikes. The PPI integrates both the distance between the recruitment and mortality lines (recruitment minus mortality) and the distance of the equilibrium from zero. PPI can be calculated from $r$ and $\mathrm{K}$ :

$$
P P I=\frac{r K^{2}}{6}
$$

We define the PPI response $\left(R_{\mathrm{PPI}}\right)$ due to a mortality increase as the percentage change in PPI:

$$
R_{p p i}=\frac{P P I_{i}}{P P I}-1
$$


PPIi = PPI at increased mortality. This response can be calculated from recruitment and mortality values (see Annex 1):

$$
R_{P P I}=\frac{\left(r_{1 i}-m_{i}\right)\left(1-\frac{m_{i}}{r_{1 i}}\right)^{2}}{\left(r_{1}-m\right)\left(1-\frac{m}{r_{1}}\right)^{2}}-1
$$

In which $r_{1}$ is the recruitment at low densities, $m$ is adult mortality, $r_{1 i}$ in the recruitment at low densities at increased mortality, $m_{i}$ is the increased mortality. So $m_{i}=m(1+i)$ and $r_{1 i}=r_{1}(1-i)$ and $i$ is the percentage increase in mortality. We thus assume that the recruitment is affected to the same extent (i.e. by the same proportional reduction) as adult mortality. In reality, the consequences of a $1 \%$ increase in adult mortality for recruitment may not be that straightforward. It seems fair to assume that an increased adult mortality corresponds with an increased juvenile mortality, although the relative vulnerability to collisions by different age classes is often unknown. Adult mortality may also lead to decreased breeding success when adults are killed and the nesting attempt fails. Since recruitment of breeding birds into the population consists of a reproduction term (i.e. number of fledglings) and a survival term (from fledging to age of first breeding) we decided to translate a $1 \%$ increase in adult mortality into a $1 \%$ decrease in recruitment. This is the case only when survival from fledgling to breeding adult is 0.5 and age of first breeding is one year; in such cases, $1 \%$ extra mortality equals $1 \%$ decreased survival - ignoring the consequences of the death of a parent bird. In all other situations the decrease in recruitment is not exactly the same as the increase in mortality extra parameters such as juvenile survival, number of fledglings, and age of first breeding are needed to calculate the exact decrease in recruitment. In any case, $r_{1 i}$ can be estimated from population parameters and equation 6 to estimate the response $\mathrm{R}_{\mathrm{PPI}}$. Note that the carrying capacity $\mathrm{K}$ is an important ingredient of the PPI but does not affect the PPI response.

We analyse this response of PPI for various $r_{1}$ and $m$ values increasing the mortality and decreasing the recruitment by $0.5,1,2$ and $5 \%$ to assess the impact of such increased mortality and decreased recruitment on population persistence.

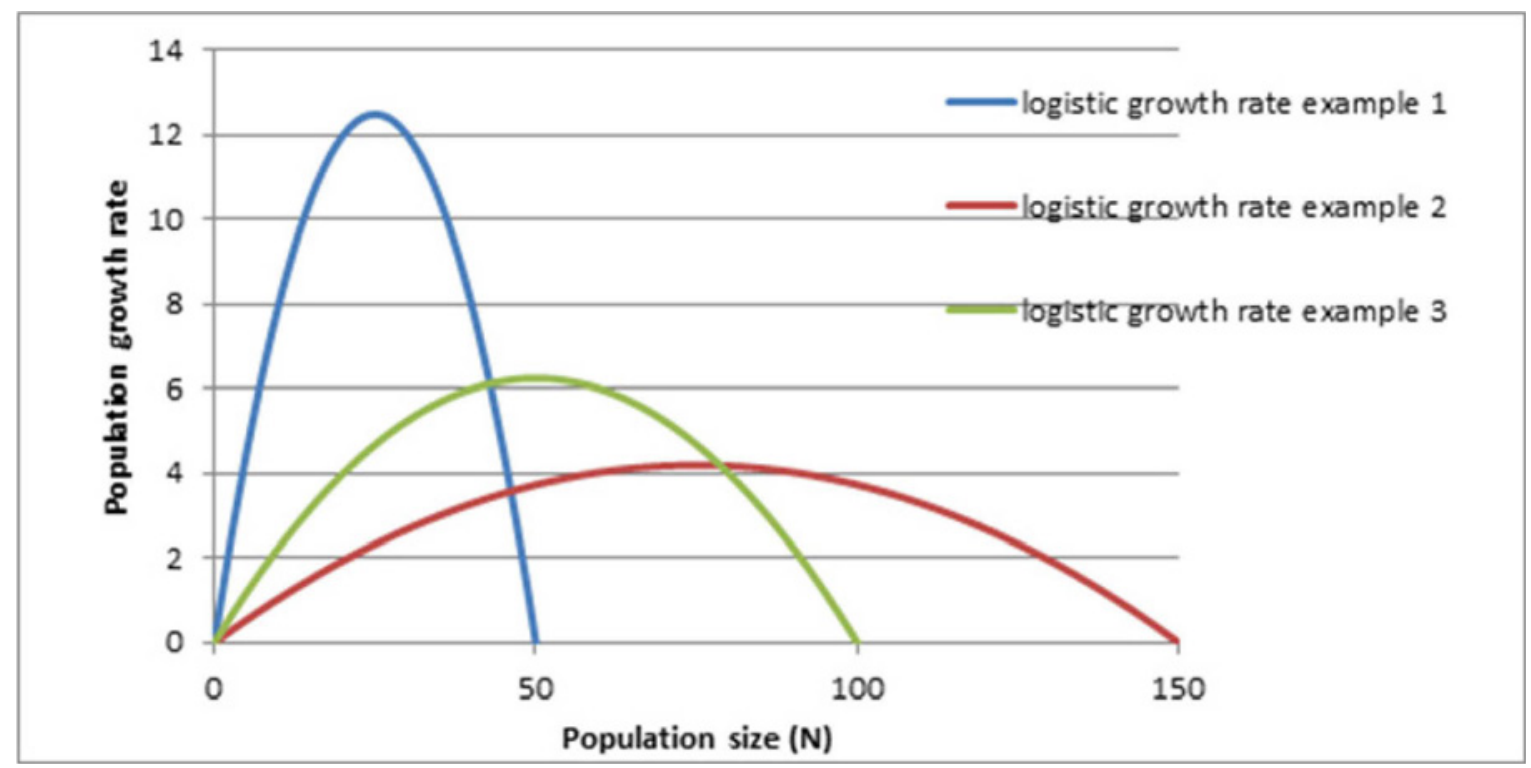

Figure 3 Illustrating the role of $r$, maximum population growth rate, and $K$, carrying capacity (or equilibrium size) on the Population Persistence Index PPI (area under the curve), for three healthy populations with the same PPI. The larger population with a higher $K$ but a lower $r$ has the same PPI, and thus persistence when confronted with additional mortality, as the smaller population with a smaller $K$ but a higher $r$. 


\subsection{Assessing the effects of PBR on the Population Persistence Index}

De Potential Biological Removal is defined as (Wade 1998):

$$
P B R=0.5 \cdot N \cdot r \cdot F_{r}
$$

In which $\mathrm{r}=$ relative growth rate, $\mathrm{N}=$ population size, $\mathrm{F}_{\mathrm{r}}=$ adjustment factor for population sensitivity (also termed a "recovery factor"; Wade 1998). Subtracting this "removal" from the logistic growth equation yields a new PPI curve (Figure 5A and Annex 2). If we define the response $\mathrm{R}_{\mathrm{PPI}}$ to be the relative PPI under PBR harvesting divided by the PPI without harvesting, we can calculate the response to be (Annex 2 ):

$$
R_{P P I}=\frac{P P I_{P B R}}{P P I_{u}}=\left(1-0.5 F_{r}\right)^{3}
$$

Note that $R_{\text {ppi, }}$ the proportional change in PPI, is independent of $r$ and $K$ and depends only on $F_{r}$.

\subsection{Effect of increased mortality - case studies}

We evaluate the impact of additional mortality through wind turbine strikes on populations of two vulnerable species in the Netherlands: the Common Tern in the Waddenzee and Ijsselmeer area, and Dutch population of Marsh Harrier. We used the available capture-mark-recapture data to estimate the mortality rate of adult Marsh Harriers (Annex 3), and used known mortality rates for Common Tern; mortality rates were assumed to be density-independent. The recruitment rate is strongly densitydependent and therefore often lower than the maximum recruitment rate of a given population. Also, recruitment rates are inherently difficult to measure at near-zero population densities. We therefore approximated the maximum recruitment (for the case of no density effect of conspecifics) by using recruitment data obtained in years with relatively high breeding success, assuming that intraspecific competition is low during such years (e.g. because of superfluous food supply). We subsequently estimated the maximum recruitment rate to adulthood $\left(r_{1}\right)$ and the adult mortality rate $(m)$, as well as the maximum recruitment rate at increased mortality $\left(r_{1 i}\right)$ and the increased mortality $\left(m_{i}\right)$ after a hypothetical increase in mortality due to wind turbine strike, in a continuous time model. These estimates were substituted in equation (6) to assess the proportional response of the Population Persistence Index (PPI) to increased mortality after introduction of wind turbines.

\section{Common Tern}

Mortality rates for the Common Tern for the Waddenzee population, including the Northern part of IJsselmeer between 1991-2010 were derived from Van der Jeugd et al. (2014). The total Waddenzee and IJsselmeer population is estimated at 7,630 pairs (average population 2010-2014; Sovon 2016), constituting c. $40 \%$ of the Dutch breeding population of 20.000 pairs (Sovon 2016). Since the end of last century the breeding population and the non-breeding population of Common Tern declined by about $50 \%$ of its size in 1990 (Sovon 2016). The mean number of fledglings per pair was 0.67 in the Delfzijl area, where the reproductive rates are thought to be among the highest in the Netherlands (Brenninkmeijer and Klop 2015). We used the mean nest success in the three years with the highest nest success in this area to estimate the recruitment rate of a Common Tern population experiencing maximum population growth.

\section{Marsh Harrier}

Survival rates and mean reproductive success for the Dutch breeding population of Marsh Harrier were estimated for 1997-2015 using respectively ring recoveries available at Vogeltrekstation NIOO-KNAW and data on nest success at the Dutch Raptor Working Group (Annex 3 and 4). Annual survival of Marsh Harriers was analysed using live re-sightings and dead recoveries of 12.059 birds ringed as nestling between 1991 and 2016 and 74 birds ringed as 'adult' in the same period (due to low sample sizes, birds ringed in their first and second calendar year were lumped with older birds in the 'adult' 
category). Nest success was estimated using data on 1914 nests, which were followed from the beginning to the end of the nest cycle, in the Netherlands between 1997 and 2015. Of these, we used the mean nest success in the three years with the highest nest success to estimate the recruitment rate of the Marsh Harrier population experiencing maximum population growth. 


\section{Results}

\subsection{Impact of increased mortality and decreased recruitment on the Population Persistence Index}

The PPI is especially sensitive to additional mortality in populations in which the mortality approaches the maximum recruitment $r_{1}$ (Figure 4). In theory a $100 \%$ decline in PPI can occur in such populations, meaning that there is a small area under the curve that disappears with increased mortality resulting in a declining population. The high sensitivity applies across the range of species where mortality approaches the maximum recruitment, and is similar for those with low recruitment rates and low mortality rates and those with high recruitment and high mortality rates. Species or populations at the right upper corner in Figure 4 are not realistically parameterised because they combine a high recruitment and a low adult mortality - in reality, a trade-off usually exists and species cannot simultaneously invest in survival and in recruitment, which cannot both be high. However, invasive species with few natural enemies and abundant resources could in some cases fit in this category; these are sometimes called "Darwinian Demons" because a combination of high recruitment and low mortality would lead to extinction and therefore non-existence under natural selection pressures (Law 1979). Conversely, in the lower left corner are those species or populations that combine high mortality and low recruitment. Such species cannot persist under normal conditions; populations in this part of the parameter space have to deal with an "extinction debt" and are often referred to as "living dead" or "ghost of the landscape past" populations (Tilman et al. 1994, Nagelkerke et al. 2002). Realistically parameterised species or populations, situated along the diagonal, are much more sensitive.

The area response or loss of population persistence (PPI) for "realistic species" is generally much higher than the mortality increase e.g. the effects of $1 \%$ increase in mortality to natural mortality can induce responses between $1.6 \%$ and $100 \%$. For any $5 \%$ increase in mortality to natural mortality the loss in PPI is even higher, between $20 \%$ and $100 \%$.

\begin{tabular}{|c|c|c|c|c|c|c|c|c|c|c|c|c|c|c|c|c|c|c|c|c|c|c|c|c|}
\hline \multirow[t]{2}{*}{ A (0.5\%) } & \multicolumn{3}{|c|}{ Recruitment (r1) } & \multirow[b]{2}{*}{0.11} & \multirow[b]{2}{*}{0.12} & \multirow[b]{2}{*}{0.14} & \multirow[b]{2}{*}{0.16} & \multirow[b]{2}{*}{0.19} & \multirow[b]{2}{*}{0.21} & \multirow[b]{2}{*}{0.25} & \multirow[b]{2}{*}{0.28} & \multirow[b]{2}{*}{0.33} & \multirow[b]{2}{*}{0.37} & \multirow[b]{2}{*}{0.43} & \multirow[b]{2}{*}{0.50} & \multirow[b]{2}{*}{0.57} & \multirow{3}{*}{0.66} & \multirow{3}{*}{0.75} & \multirow{3}{*}{0.87} & \multirow{3}{*}{1.00} & \multirow{3}{*}{1.15} & \multirow{3}{*}{1.32} & \multirow{3}{*}{1.52} & \multirow[b]{2}{*}{1.74} \\
\hline & $\begin{array}{ll}0.07 \\
\end{array}$ & 0.08 & 0.09 & & & & & & & & & & & & & & & & & & & & & \\
\hline Adult mort. (m) & & & & & & & & & & & & & & & & & & & & & & & & \\
\hline 0.07 & NS & $-19.2 \%$ & $-9.5 \%$ & $-6.1 \%$ & $-4.5 \%$ & $-3.4 \%$ & $-2.8 \%$ & $-2.3 \%$ & $-1.9 \%$ & $-1.7 \%$ & $-1.5 \%$ & $-1.3 \%$ & $-1.2 \%$ & $-1.1 \%$ & $-1.0 \%$ & $-0.9 \%$ & $-0.9 \%$ & $-0.8 \%$ & $-0.8 \%$ & $-0.7 \%$ & $-0.7 \%$ & $-0.7 \%$ & $-0.6 \%$ & $-0.6 \%$ \\
\hline 0.08 & NS & NS & $-19.2 \%$ & $-9.5 \%$ & $-6.1 \%$ & $-4.5 \%$ & $-3.4 \%$ & $-2.8 \%$ & $-2.3 \%$ & $-1.9 \%$ & $-1.7 \%$ & $-1.5 \%$ & $-1.3 \%$ & $-1.2 \%$ & $-1.1 \%$ & $-1.0 \%$ & $-0.9 \%$ & $-0.9 \%$ & $-0.8 \%$ & $-0.8 \%$ & $-0.7 \%$ & $-0.7 \%$ & $-0.7 \%$ & $-0.6 \%$ \\
\hline 0.09 & NS & NS & NS & $-19.2 \%$ & $-9.5 \%$ & $-6.1 \%$ & $-4.5 \%$ & $-3.4 \%$ & $-2.8 \%$ & $-2.3 \%$ & $-1.9 \%$ & $-1.7 \%$ & $-1.5 \%$ & $-1.3 \%$ & $-1.2 \%$ & $-1.1 \%$ & $-1.0 \%$ & $-0.9 \%$ & $-0.9 \%$ & $-0.8 \%$ & $-0.8 \%$ & $-0.7 \%$ & $-0.7 \%$ & $-0.7 \%$ \\
\hline 0.11 & NS & NS & NS & NS & $-19.2 \%$ & $-9.5 \%$ & $-6.1 \%$ & $-4.5 \%$ & $-3.4 \%$ & $-2.8 \%$ & $-2.3 \%$ & $-1.9 \%$ & $-1.7 \%$ & $-1.5 \%$ & $-1.3 \%$ & $-1.2 \%$ & $-1.1 \%$ & $-1.0 \%$ & $-0.9 \%$ & $-0.9 \%$ & $-0.8 \%$ & $-0.8 \%$ & $-0.7 \%$ & $-0.7 \%$ \\
\hline 0.12 & NS & NS & NS & NS & NS & $-19.2 \%$ & $-9.5 \%$ & $-6.1 \%$ & $-4.5 \%$ & $-3.4 \%$ & $-2.8 \%$ & $-2.3 \%$ & $-1.9 \%$ & $-1.7 \%$ & $-1.5 \%$ & $-1.3 \%$ & $-1.2 \%$ & $-1.1 \%$ & $-1.0 \%$ & $-0.9 \%$ & $-0.9 \%$ & $-0.8 \%$ & $-0.8 \%$ & $-0.7 \%$ \\
\hline 0.14 & NS & NS & NS & NS & NS & NS & $-19.2 \%$ & $-9.5 \%$ & $-6.1 \%$ & $-4.5 \%$ & $-3.4 \%$ & $-2.8 \%$ & $-2.3 \%$ & $-1.9 \%$ & $-1.7 \%$ & $-1.5 \%$ & $-1.3 \%$ & $-1.2 \%$ & $-1.1 \%$ & $-1.0 \%$ & $-0.9 \%$ & $-0.9 \%$ & $-0.8 \%$ & $-0.8 \%$ \\
\hline 0.16 & NS & NS & NS & NS & NS & NS & NS & $-19.2 \%$ & $-9.5 \%$ & $-6.1 \%$ & $-4.5 \%$ & $-3.4 \%$ & $-2.8 \%$ & $-2.3 \%$ & $-1.9 \%$ & $-1.7 \%$ & $-1.5 \%$ & $-1.3 \%$ & $-1.2 \%$ & $-1.1 \%$ & $-1.0 \%$ & $-0.9 \%$ & $-0.9 \%$ & $-0.8 \%$ \\
\hline 0.19 & NS & NS & NS & NS & NS & NS & NS & NS & $-19.2 \%$ & $-9.5 \%$ & $-6.1 \%$ & $-4.5 \%$ & $-3.4 \%$ & $-2.8 \%$ & $-2.3 \%$ & $-1.9 \%$ & $-1.7 \%$ & $-1.5 \%$ & $-1.3 \%$ & $-1.2 \%$ & $-1.1 \%$ & $-1.0 \%$ & $-0.9 \%$ & $-0.9 \%$ \\
\hline 0.21 & NS & NS & NS & NS & NS & NS & NS & NS & NS & $-19.2 \%$ & $-9.5 \%$ & $-6.1 \%$ & $-4.5 \%$ & $-3.4 \%$ & $-2.8 \%$ & $-2.3 \%$ & $-1.9 \%$ & $-1.7 \%$ & $-1.5 \%$ & $-1.3 \%$ & $-1.2 \%$ & $-1.1 \%$ & $-1.0 \%$ & $-0.9 \%$ \\
\hline 0.25 & NS & NS & NS & NS & NS & NS & NS & NS & NS & NS & $-19.2 \%$ & $-9.5 \%$ & $-6.1 \%$ & $-4.5 \%$ & $-3.4 \%$ & $-2.8 \%$ & $-2.3 \%$ & $-1.9 \%$ & $-1.7 \%$ & $-1.5 \%$ & $-1.3 \%$ & $-1.2 \%$ & $-1.1 \%$ & $-1.0 \%$ \\
\hline 0.28 & NS & NS & NS & NS & NS & NS & NS & NS & NS & NS & NS & $-19.2 \%$ & $-9.5 \%$ & $-6.1 \%$ & $-4.5 \%$ & $-3.4 \%$ & $-2.8 \%$ & $-2.3 \%$ & $-1.9 \%$ & $-1.7 \%$ & $-1.5 \%$ & $-1.3 \%$ & $-1.2 \%$ & $-1.1 \%$ \\
\hline 0.33 & NS & NS & NS & NS & NS & NS & NS & NS & NS & NS & NS & NS & $-19.2 \%$ & $-9.5 \%$ & $-6.1 \%$ & $-4.5 \%$ & $-3.4 \%$ & $-2.8 \%$ & $-2.3 \%$ & $-1.9 \%$ & $-1.7 \%$ & $-1.5 \%$ & $-1.3 \%$ & $-1.2 \%$ \\
\hline 0.37 & NS & NS & NS & NS & NS & NS & NS & NS & NS & NS & NS & NS & NS & $-19.2 \%$ & $-9.5 \%$ & $-6.1 \%$ & $-4.5 \%$ & $-3.4 \%$ & $-2.8 \%$ & $-2.3 \%$ & $-1.9 \%$ & $-1.7 \%$ & $-1.5 \%$ & $-1.3 \%$ \\
\hline 0.43 & NS & NS & NS & NS & NS & NS & NS & NS & NS & NS & NS & NS & NS & NS & $-19.2 \%$ & $-9.5 \%$ & $-6.1 \%$ & $-4.5 \%$ & $-3.4 \%$ & $-2.8 \%$ & $-2.3 \%$ & $-1.9 \%$ & $-1.7 \%$ & $-1.5 \%$ \\
\hline 0.50 & NS & NS & NS & NS & NS & NS & NS & NS & NS & NS & NS & NS & NS & NS & NS & $-19.2 \%$ & $-9.5 \%$ & $-6.1 \%$ & $-4.5 \%$ & $-3.4 \%$ & $-2.8 \%$ & $-2.3 \%$ & $-1.9 \%$ & $-1.7 \%$ \\
\hline 0.57 & NS & NS & NS & NS & NS & NS & NS & NS & NS & NS & NS & NS & NS & NS & NS & NS & $-19.2 \%$ & $-9.5 \%$ & $-6.1 \%$ & $-4.5 \%$ & $-3.4 \%$ & $-2.8 \%$ & $-2.3 \%$ & $-1.9 \%$ \\
\hline 0.66 & NS & NS & NS & NS & NS & NS & NS & NS & NS & NS & NS & NS & NS & NS & NS & NS & NS & $-19.2 \%$ & $-9.5 \%$ & $-6.1 \%$ & $-4.5 \%$ & $-3.4 \%$ & $-2.8 \%$ & $-2.3 \%$ \\
\hline 0.75 & NS & NS & NS & NS & NS & NS & NS & NS & NS & NS & NS & NS & NS & NS & NS & NS & NS & NS & $-19.2 \%$ & $-9.5 \%$ & $-6.1 \%$ & $-4.5 \%$ & $-3.4 \%$ & $-2.8 \%$ \\
\hline 0.87 & NS & NS & NS & NS & NS & NS & NS & NS & NS & NS & NS & NS & NS & NS & NS & NS & NS & NS & NS & $-19.2 \%$ & $-9.5 \%$ & $-6.1 \%$ & $-4.5 \%$ & $-3.4 \%$ \\
\hline 1.00 & NS & NS & NS & NS & NS & NS & NS & NS & NS & NS & NS & NS & NS & NS & NS & NS & NS & NS & NS & NS & $-19.2 \%$ & $-9.5 \%$ & $-6.1 \%$ & $-4.5 \%$ \\
\hline 1.15 & NS & NS & NS & NS & NS & NS & NS & NS & NS & NS & NS & NS & NS & NS & NS & NS & NS & NS & NS & NS & NS & $-19.2 \%$ & $-9.5 \%$ & $-6.1 \%$ \\
\hline 1.32 & NS & NS & NS & NS & NS & NS & NS & NS & NS & NS & NS & NS & NS & NS & NS & NS & NS & NS & NS & NS & NS & NS & $-19.2 \%$ & $-9.5 \%$ \\
\hline 1.52 & NS & NS & NS & NS & NS & NS & NS & NS & NS & NS & NS & NS & NS & NS & NS & NS & NS & NS & NS & NS & NS & NS & NS & $-19.2 \%$ \\
\hline 1.74 & NS & NS & NS & NS & NS & NS & NS & NS & NS & NS & NS & NS & NS & NS & NS & NS & NS & NS & NS & NS & NS & NS & NS & NS \\
\hline
\end{tabular}




\begin{tabular}{|c|c|c|c|c|c|c|c|c|c|c|c|c|c|c|c|c|c|c|c|c|c|c|c|c|}
\hline \multirow[t]{2}{*}{ B (1\%) } & \multicolumn{3}{|c|}{ Recruitment ( $\mathrm{r} 1)$} & \multirow[b]{2}{*}{0.11} & \multirow[b]{2}{*}{0.12} & \multirow[b]{2}{*}{0.14} & \multirow[b]{2}{*}{0.16} & \multirow[b]{2}{*}{0.19} & \multirow[b]{2}{*}{0.21} & \multirow[b]{2}{*}{0.25} & \multirow[b]{2}{*}{0.28} & \multirow[b]{2}{*}{0.33} & \multirow[b]{2}{*}{0.37} & \multirow[b]{2}{*}{0.43} & \multirow[b]{2}{*}{0.50} & \multirow[b]{2}{*}{0.57} & \multirow[b]{2}{*}{0.66} & \multirow[b]{2}{*}{0.75} & \multirow[b]{2}{*}{0.87} & \multirow[b]{2}{*}{1.00} & \multirow[b]{2}{*}{1.15} & \multirow{3}{*}{1.32} & \multirow{3}{*}{1.52} & \multirow[b]{2}{*}{1.74} \\
\hline & 0.07 & 0.08 & 0.09 & & & & & & & & & & & & & & & & & & & & & \\
\hline Adult mort.(m) & & & & & & & & & & & & & & & & & & & & & & & & \\
\hline 0.07 & NS & $-35.9 \%$ & $-18.5 \%$ & $-12.1 \%$ & $-8.8 \%$ & $-6.8 \%$ & $-5.5 \%$ & $-4.6 \%$ & $-3.9 \%$ & $-3.4 \%$ & $-3.0 \%$ & $-2.6 \%$ & $-2.4 \%$ & $-2.2 \%$ & $-2.0 \%$ & $-1.8 \%$ & $-1.7 \%$ & $-1.6 \%$ & $-1.5 \%$ & $-1.5 \%$ & $-1.4 \%$ & $-1.3 \%$ & $-1.3 \%$ & $-1.3 \%$ \\
\hline 0.08 & NS & NS & $-35.9 \%$ & $-18.5 \%$ & $-12.1 \%$ & $-8.8 \%$ & $-6.8 \%$ & $-5.5 \%$ & $-4.6 \%$ & $-3.9 \%$ & $-3.4 \%$ & $-3.0 \%$ & $-2.6 \%$ & $-2.4 \%$ & $-2.2 \%$ & $-2.0 \%$ & $-1.8 \%$ & $-1.7 \%$ & $-1.6 \%$ & $-1.5 \%$ & $-1.5 \%$ & $-1.4 \%$ & $-1.3 \%$ & $-1.3 \%$ \\
\hline 0.09 & NS & NS & NS & $-35.9 \%$ & $-18.5 \%$ & $-12.1 \%$ & $-8.8 \%$ & $-6.8 \%$ & $-5.5 \%$ & $-4.6 \%$ & $-3.9 \%$ & $-3.4 \%$ & $-3.0 \%$ & $-2.6 \%$ & $-2.4 \%$ & $-2.2 \%$ & $-2.0 \%$ & $-1.8 \%$ & $-1.7 \%$ & $-1.6 \%$ & $-1.5 \%$ & $-1.5 \%$ & $-1.4 \%$ & $-1.3 \%$ \\
\hline 0.11 & NS & NS & NS & NS & $-35.9 \%$ & $-18.5 \%$ & $-12.1 \%$ & $-8.8 \%$ & $-6.8 \%$ & $-5.5 \%$ & $-4.6 \%$ & $-3.9 \%$ & $-3.4 \%$ & $-3.0 \%$ & $-2.6 \%$ & $-2.4 \%$ & $-2.2 \%$ & $-2.0 \%$ & $-1.8 \%$ & $-1.7 \%$ & $-1.6 \%$ & $-1.5 \%$ & $-1.5 \%$ & $-1.4 \%$ \\
\hline 0.12 & NS & NS & NS & NS & NS & $-35.9 \%$ & $-18.5 \%$ & $-12.1 \%$ & $-8.8 \%$ & $-6.8 \%$ & $-5.5 \%$ & $-4.6 \%$ & $-3.9 \%$ & $-3.4 \%$ & $-3.0 \%$ & $-2.6 \%$ & $-2.4 \%$ & $-2.2 \%$ & $-2.0 \%$ & $-1.8 \%$ & $-1.7 \%$ & $-1.6 \%$ & $-1.5 \%$ & $-1.5 \%$ \\
\hline 0.14 & NS & NS & NS & NS & NS & NS & $-35.9 \%$ & $-18.5 \%$ & $-12.1 \%$ & $-8.8 \%$ & $-6.8 \%$ & $-5.5 \%$ & $-4.6 \%$ & $-3.9 \%$ & $-3.4 \%$ & $-3.0 \%$ & $-2.6 \%$ & $-2.4 \%$ & $-2.2 \%$ & $-2.0 \%$ & $-1.8 \%$ & $-1.7 \%$ & $-1.6 \%$ & $-1.5 \%$ \\
\hline 0.16 & NS & NS & NS & NS & NS & NS & NS & $-35.9 \%$ & $-18.5 \%$ & $-12.1 \%$ & $-8.8 \%$ & $-6.8 \%$ & $-5.5 \%$ & $-4.6 \%$ & $-3.9 \%$ & $-3.4 \%$ & $-3.0 \%$ & $-2.6 \%$ & $-2.4 \%$ & $-2.2 \%$ & $-2.0 \%$ & $-1.8 \%$ & $-1.7 \%$ & $-1.6 \%$ \\
\hline 0.19 & NS & NS & NS & NS & NS & NS & NS & NS & $-35.9 \%$ & $-18.5 \%$ & $-12.1 \%$ & $-8.8 \%$ & $-6.8 \%$ & $-5.5 \%$ & $-4.6 \%$ & $-3.9 \%$ & $-3.4 \%$ & $-3.0 \%$ & $-2.6 \%$ & $-2.4 \%$ & $-2.2 \%$ & $-2.0 \%$ & $-1.8 \%$ & $-1.7 \%$ \\
\hline 0.21 & NS & NS & NS & NS & NS & NS & NS & NS & NS & $-35.9 \%$ & $-18.5 \%$ & $-12.1 \%$ & $-8.8 \%$ & $-6.8 \%$ & $-5.5 \%$ & $-4.6 \%$ & $-3.9 \%$ & $-3.4 \%$ & $-3.0 \%$ & $-2.6 \%$ & $-2.4 \%$ & $-2.2 \%$ & $-2.0 \%$ & $-1.8 \%$ \\
\hline 0.25 & NS & NS & NS & NS & NS & NS & NS & NS & NS & NS & $-35.9 \%$ & $-18.5 \%$ & $-12.1 \%$ & $-8.8 \%$ & $-6.8 \%$ & $-5.5 \%$ & $-4.6 \%$ & $-3.9 \%$ & $-3.4 \%$ & $-3.0 \%$ & $-2.6 \%$ & $-2.4 \%$ & $-2.2 \%$ & $-2.0 \%$ \\
\hline 0.28 & NS & NS & NS & NS & NS & NS & NS & NS & NS & NS & NS & $-35.9 \%$ & $-18.5 \%$ & $-12.1 \%$ & $-8.8 \%$ & $-6.8 \%$ & $-5.5 \%$ & $-4.6 \%$ & $-3.9 \%$ & $-3.4 \%$ & $-3.0 \%$ & $-2.6 \%$ & $-2.4 \%$ & $-2.2 \%$ \\
\hline 0.33 & NS & NS & NS & NS & NS & NS & NS & NS & NS & NS & NS & NS & $-35.9 \%$ & $-18.5 \%$ & $-12.1 \%$ & $-8.8 \%$ & $-6.8 \%$ & $-5.5 \%$ & $-4.6 \%$ & $-3.9 \%$ & $-3.4 \%$ & $-3.0 \%$ & $-2.6 \%$ & $-2.4 \%$ \\
\hline 0.37 & NS & NS & NS & NS & NS & NS & NS & NS & NS & NS & NS & NS & NS & $-35.9 \%$ & $-18.5 \%$ & $-12.1 \%$ & $-8.8 \%$ & $-6.8 \%$ & $-5.5 \%$ & $-4.6 \%$ & $-3.9 \%$ & $-3.4 \%$ & $-3.0 \%$ & $-2.6 \%$ \\
\hline 0.43 & NS & NS & NS & NS & NS & NS & NS & NS & NS & NS & NS & NS & NS & NS & $-35.9 \%$ & $-18.5 \%$ & $-12.1 \%$ & $-8.8 \%$ & $-6.8 \%$ & $-5.5 \%$ & $-4.6 \%$ & $-3.9 \%$ & $-3.4 \%$ & $-3.0 \%$ \\
\hline 0.50 & NS & NS & NS & NS & NS & NS & NS & NS & NS & NS & NS & NS & NS & NS & NS & $-35.9 \%$ & $-18.5 \%$ & $-12.1 \%$ & $-8.8 \%$ & $-6.8 \%$ & $-5.5 \%$ & $-4.6 \%$ & $-3.9 \%$ & $-3.4 \%$ \\
\hline 0.57 & NS & NS & NS & NS & NS & NS & NS & NS & NS & NS & NS & NS & NS & NS & NS & NS & $-35.9 \%$ & $-18.5 \%$ & $-12.1 \%$ & $-8.8 \%$ & $-6.8 \%$ & $-5.5 \%$ & $-4.6 \%$ & $-3.9 \%$ \\
\hline 0.66 & NS & NS & NS & NS & NS & NS & NS & NS & NS & NS & NS & NS & NS & NS & NS & NS & NS & $-35.9 \%$ & $-18.5 \%$ & $-12.1 \%$ & $-8.8 \%$ & $-6.8 \%$ & $-5.5 \%$ & $-4.6 \%$ \\
\hline 0.75 & NS & NS & NS & NS & NS & NS & NS & NS & NS & NS & NS & NS & NS & NS & NS & NS & NS & NS & $-35.9 \%$ & $-18.5 \%$ & $-12.1 \%$ & $-8.8 \%$ & $-6.8 \%$ & $-5.5 \%$ \\
\hline 0.87 & NS & NS & NS & NS & NS & NS & NS & NS & NS & NS & NS & NS & NS & NS & NS & NS & NS & NS & NS & $-35.9 \%$ & $-18.5 \%$ & $-12.1 \%$ & $-8.8 \%$ & $-6.8 \%$ \\
\hline 1.00 & NS & NS & NS & NS & NS & NS & NS & NS & NS & NS & NS & NS & NS & NS & NS & NS & NS & NS & NS & NS & $-35.9 \%$ & $-18.5 \%$ & $-12.1 \%$ & $-8.8 \%$ \\
\hline 1.15 & NS & NS & NS & NS & NS & NS & NS & NS & NS & NS & NS & NS & NS & NS & NS & NS & NS & NS & NS & NS & NS & $-35.9 \%$ & $-18.5 \%$ & $-12.1 \%$ \\
\hline 1.32 & NS & NS & NS & NS & NS & NS & NS & NS & NS & NS & NS & NS & NS & NS & NS & NS & NS & NS & NS & NS & NS & NS & $-35.9 \%$ & $-18.5 \%$ \\
\hline 1.52 & NS & NS & NS & NS & NS & NS & NS & NS & NS & NS & NS & NS & NS & NS & NS & NS & NS & NS & NS & NS & NS & NS & NS & $-35.9 \%$ \\
\hline 1.74 & NS & NS & NS & NS & NS & NS & NS & NS & NS & NS & NS & NS & NS & NS & NS & NS & NS & NS & NS & NS & NS & NS & NS & NS \\
\hline
\end{tabular}

\begin{tabular}{|c|c|c|c|c|c|c|c|c|c|c|c|c|c|c|c|c|c|c|c|c|c|c|c|c|}
\hline \multirow[t]{2}{*}{ C (2\%) } & \multicolumn{3}{|c|}{ Recruitment (r1) } & \multirow[b]{2}{*}{0.11} & \multirow[b]{2}{*}{0.12} & \multirow[b]{2}{*}{0.14} & \multirow[b]{2}{*}{0.16} & \multirow[b]{2}{*}{0.19} & \multirow[b]{2}{*}{0.21} & \multirow[b]{2}{*}{0.25} & \multirow[b]{2}{*}{0.28} & \multirow[b]{2}{*}{0.33} & \multirow[b]{2}{*}{0.37} & \multirow[b]{2}{*}{0.43} & \multirow[b]{2}{*}{0.50} & \multirow{3}{*}{0.57} & \multirow{3}{*}{0.66} & \multirow{3}{*}{0.75} & \multirow{3}{*}{0.87} & \multirow{3}{*}{1.00} & \multirow{3}{*}{1.15} & \multirow{3}{*}{1.32} & \multirow{3}{*}{1.52} & \multirow[b]{2}{*}{1.74} \\
\hline & 0.07 & 0.08 & 0.09 & & & & & & & & & & & & & & & & & & & & & \\
\hline Adult mort. (m) & & & & & & & & & & & & & & & & & & & & & & & & \\
\hline 0.07 & NS & -62.29 & $-34.7 \%$ & $-23.3 \%$ & $-17.2 \%$ & $-13.4 \%$ & $-10.9 \%$ & $-9.1 \%$ & $-7.7 \%$ & $-6.7 \%$ & $-5.9 \%$ & $-5.2 \%$ & $-4.7 \%$ & $-4.3 \%$ & $-4.0 \%$ & $-3.7 \%$ & $-3.4 \%$ & $-3.2 \%$ & $-3.1 \%$ & $-2.9 \%$ & $-2.8 \%$ & $-2.7 \%$ & $-2.6 \%$ & $-2.5 \%$ \\
\hline 0.08 & NS & NS & $-62.2 \%$ & $-34.7 \%$ & $-23.3 \%$ & $-17.2 \%$ & $-13.4 \%$ & $-10.9 \%$ & $-9.1 \%$ & $-7.7 \%$ & $-6.7 \%$ & $-5.9 \%$ & $-5.2 \%$ & $-4.7 \%$ & $-4.3 \%$ & $-4.0 \%$ & $-3.7 \%$ & $-3.4 \%$ & $-3.2 \%$ & $-3.1 \%$ & $-2.9 \%$ & $-2.8 \%$ & $-2.7 \%$ & $-2.6 \%$ \\
\hline 0.09 & NS & NS & NS & $-62.2 \%$ & $-34.7 \%$ & $-23.3 \%$ & $-17.2 \%$ & $-13.4 \%$ & $-10.9 \%$ & $-9.1 \%$ & $-7.7 \%$ & $-6.7 \%$ & $-5.9 \%$ & $-5.2 \%$ & $-4.7 \%$ & $-4.3 \%$ & $-4.0 \%$ & $-3.7 \%$ & $-3.4 \%$ & $-3.2 \%$ & $-3.1 \%$ & $-2.9 \%$ & $-2.8 \%$ & $-2.7 \%$ \\
\hline 0.11 & NS & NS & NS & NS & $-62.2 \%$ & $-34.7 \%$ & $-23.3 \%$ & $-17.2 \%$ & $-13.4 \%$ & $-10.9 \%$ & $-9.1 \%$ & $-7.7 \%$ & $-6.7 \%$ & $-5.9 \%$ & $-5.2 \%$ & $-4.7 \%$ & $-4.3 \%$ & $-4.0 \%$ & $-3.7 \%$ & $-3.4 \%$ & $-3.2 \%$ & $-3.1 \%$ & $-2.9 \%$ & $-2.8 \%$ \\
\hline 0.12 & NS & NS & NS & NS & NS & $-62.2 \%$ & $-34.7 \%$ & $-23.3 \%$ & $-17.2 \%$ & $-13.4 \%$ & $-10.9 \%$ & $-9.1 \%$ & $-7.7 \%$ & $-6.7 \%$ & $-5.9 \%$ & $-5.2 \%$ & $-4.7 \%$ & $-4.3 \%$ & $-4.0 \%$ & $-3.7 \%$ & $-3.4 \%$ & $-3.2 \%$ & $-3.1 \%$ & $-2.9 \%$ \\
\hline 0.14 & NS & NS & NS & NS & NS & NS & $-62.2 \%$ & $-34.7 \%$ & $-23.3 \%$ & $-17.2 \%$ & $-13.4 \%$ & $-10.9 \%$ & $-9.1 \%$ & $-7.7 \%$ & $-6.7 \%$ & $-5.9 \%$ & $-5.2 \%$ & $-4.7 \%$ & $-4.3 \%$ & $-4.0 \%$ & $-3.7 \%$ & $-3.4 \%$ & $-3.2 \%$ & $-3.1 \%$ \\
\hline 0.16 & NS & NS & NS & NS & NS & NS & NS & $-62.2 \%$ & $-34.7 \%$ & $-23.3 \%$ & $-17.2 \%$ & $-13.4 \%$ & $-10.9 \%$ & $-9.1 \%$ & $-7.7 \%$ & $-6.7 \%$ & $-5.9 \%$ & $-5.2 \%$ & $-4.7 \%$ & $-4.3 \%$ & $-4.0 \%$ & $-3.7 \%$ & $-3.4 \%$ & $-3.2 \%$ \\
\hline 0.19 & NS & NS & NS & NS & NS & NS & NS & NS & $-62.2 \%$ & $-34.7 \%$ & $-23.3 \%$ & $-17.2 \%$ & $-13.4 \%$ & $-10.9 \%$ & $-9.1 \%$ & $-7.7 \%$ & $-6.7 \%$ & $-5.9 \%$ & $-5.2 \%$ & $-4.7 \%$ & $-4.3 \%$ & $-4.0 \%$ & $-3.7 \%$ & $-3.4 \%$ \\
\hline 0.21 & NS & NS & NS & NS & NS & NS & NS & NS & NS & $-62.2 \%$ & $-34.7 \%$ & $-23.3 \%$ & $-17.2 \%$ & $-13.4 \%$ & $-10.9 \%$ & $-9.1 \%$ & $-7.7 \%$ & $-6.7 \%$ & $-5.9 \%$ & $-5.2 \%$ & $-4.7 \%$ & $-4.3 \%$ & $-4.0 \%$ & $-3.7 \%$ \\
\hline 0.25 & NS & NS & NS & NS & NS & NS & NS & NS & NS & NS & $-62.2 \%$ & $-34.7 \%$ & $-23.3 \%$ & $-17.2 \%$ & $-13.4 \%$ & $-10.9 \%$ & $-9.1 \%$ & $-7.7 \%$ & $-6.7 \%$ & $-5.9 \%$ & $-5.2 \%$ & $-4.7 \%$ & $-4.3 \%$ & $-4.0 \%$ \\
\hline 0.28 & NS & NS & NS & NS & NS & NS & NS & NS & NS & NS & NS & $-62.2 \%$ & $-34.7 \%$ & $-23.3 \%$ & $-17.2 \%$ & $-13.4 \%$ & $-10.9 \%$ & $-9.1 \%$ & $-7.7 \%$ & $-6.7 \%$ & $-5.9 \%$ & $-5.2 \%$ & $-4.7 \%$ & $-4.3 \%$ \\
\hline 0.33 & NS & NS & NS & NS & NS & NS & NS & NS & NS & NS & NS & NS & $-62.2 \%$ & $-34.7 \%$ & $-23.3 \%$ & $-17.2 \%$ & $-13.4 \%$ & $-10.9 \%$ & $-9.1 \%$ & $-7.7 \%$ & $-6.7 \%$ & $-5.9 \%$ & $-5.2 \%$ & $-4.7 \%$ \\
\hline 0.37 & NS & NS & NS & NS & NS & NS & NS & NS & NS & NS & NS & NS & NS & $-62.2 \%$ & $-34.7 \%$ & $-23.3 \%$ & $-17.2 \%$ & $-13.4 \%$ & $-10.9 \%$ & $-9.1 \%$ & $-7.7 \%$ & $-6.7 \%$ & $-5.9 \%$ & $-5.2 \%$ \\
\hline 0.43 & NS & NS & NS & NS & NS & NS & NS & NS & NS & NS & NS & NS & NS & NS & $-62.2 \%$ & $-34.7 \%$ & $-23.3 \%$ & $-17.2 \%$ & $-13.4 \%$ & $-10.9 \%$ & $-9.1 \%$ & $-7.7 \%$ & $-6.7 \%$ & $-5.9 \%$ \\
\hline 0.50 & NS & NS & NS & NS & NS & NS & NS & NS & NS & NS & NS & NS & NS & NS & NS & $-62.2 \%$ & $-34.7 \%$ & $-23.3 \%$ & $-17.2 \%$ & $-13.4 \%$ & $-10.9 \%$ & $-9.1 \%$ & $-7.7 \%$ & $-6.7 \%$ \\
\hline 0.57 & NS & NS & NS & NS & NS & NS & NS & NS & NS & NS & NS & NS & NS & NS & NS & NS & $-62.2 \%$ & $-34.7 \%$ & $-23.3 \%$ & $-17.2 \%$ & $-13.4 \%$ & $-10.9 \%$ & $-9.1 \%$ & $-7.7 \%$ \\
\hline 0.66 & NS & NS & NS & NS & NS & NS & NS & NS & NS & NS & NS & NS & NS & NS & NS & NS & NS & $-62.2 \%$ & $-34.7 \%$ & $-23.3 \%$ & $-17.2 \%$ & $-13.4 \%$ & $-10.9 \%$ & $-9.1 \%$ \\
\hline 0.75 & NS & NS & NS & NS & NS & NS & NS & NS & NS & NS & NS & NS & NS & NS & NS & NS & NS & NS & $-62.2 \%$ & $-34.7 \%$ & $-23.3 \%$ & $-17.2 \%$ & $-13.4 \%$ & $-10.9 \%$ \\
\hline 0.87 & NS & NS & NS & NS & NS & NS & NS & NS & NS & NS & NS & NS & NS & NS & NS & NS & NS & NS & NS & $-62.2 \%$ & $-34.7 \%$ & $-23.3 \%$ & $-17.2 \%$ & $-13.4 \%$ \\
\hline 1.00 & NS & NS & NS & NS & NS & NS & NS & NS & NS & NS & NS & NS & NS & NS & NS & NS & NS & NS & NS & NS & $-62.2 \%$ & $-34.7 \%$ & $-23.3 \%$ & $-17.2 \%$ \\
\hline 1.15 & NS & NS & NS & NS & NS & NS & NS & NS & NS & NS & NS & NS & NS & NS & NS & NS & NS & NS & NS & NS & NS & $-62.2 \%$ & $-34.7 \%$ & $-23.3 \%$ \\
\hline 1.32 & NS & NS & NS & NS & NS & NS & NS & NS & NS & NS & NS & NS & NS & NS & NS & NS & NS & NS & NS & NS & NS & NS & $-62.2 \%$ & $-34.7 \%$ \\
\hline 1.52 & NS & NS & NS & NS & NS & NS & NS & NS & NS & NS & NS & NS & NS & NS & NS & NS & NS & NS & NS & NS & NS & NS & NS & $-62.2 \%$ \\
\hline 1.74 & NS & NS & NS & NS & NS & NS & NS & NS & NS & NS & NS & NS & NS & NS & NS & NS & NS & NS & NS & NS & NS & NS & NS & NS \\
\hline
\end{tabular}

\begin{tabular}{|c|c|c|c|c|c|c|c|c|c|c|c|c|c|c|c|c|c|c|c|c|c|c|c|c|}
\hline \multirow[t]{2}{*}{ D (5\%) } & \multicolumn{3}{|c|}{ Recruitment ( $r 1$ ) } & \multirow[b]{2}{*}{0.11} & \multirow[b]{2}{*}{0.12} & \multirow[b]{2}{*}{0.14} & \multirow[b]{2}{*}{0.16} & \multirow[b]{2}{*}{0.19} & \multirow[b]{2}{*}{0.21} & \multirow[b]{2}{*}{0.25} & \multirow[b]{2}{*}{0.28} & \multirow[b]{2}{*}{0.33} & \multirow[b]{2}{*}{0.37} & \multirow[b]{2}{*}{0.43} & \multirow[b]{2}{*}{0.50} & \multirow[b]{2}{*}{0.57} & \multirow[b]{2}{*}{0.66} & \multirow[b]{2}{*}{0.75} & \multirow[b]{2}{*}{0.87} & \multirow[b]{2}{*}{1.00} & \multirow[b]{2}{*}{1.15} & \multirow[b]{2}{*}{1.32} & \multirow{3}{*}{1.52} & \multirow[b]{2}{*}{1.74} \\
\hline & 0.07 & 0.08 & 0.09 & & & & & & & & & & & & & & & & & & & & & \\
\hline Adult mort. (m & & & & & & & & & & & & & & & & & & & & & & & & \\
\hline 0.07 & NS & $-97.5 \%$ & $-71.0 \%$ & $-51.7 \%$ & $-39.7 \%$ & $-31.7 \%$ & $-26.1 \%$ & $-22.0 \%$ & $-18.8 \%$ & $-16.4 \%$ & $-14.5 \%$ & $-13.0 \%$ & $-11.7 \%$ & $-10.7 \%$ & $-9.9 \%$ & $-9.1 \%$ & $-8.5 \%$ & $-8.0 \%$ & $-7.6 \%$ & $-7.2 \%$ & $-6.9 \%$ & $-6.7 \%$ & $-6.4 \%$ & $-6.3 \%$ \\
\hline 0.08 & NS & NS & $-97.5 \%$ & $-71.0 \%$ & $-51.7 \%$ & $-39.7 \%$ & $-31.7 \%$ & $-26.1 \%$ & $-22.0 \%$ & $-18.8 \%$ & $-16.4 \%$ & $-14.5 \%$ & $-13.0 \%$ & $-11.7 \%$ & $-10.7 \%$ & $-9.9 \%$ & $-9.1 \%$ & $-8.5 \%$ & $-8.0 \%$ & $-7.6 \%$ & $-7.2 \%$ & $-6.9 \%$ & $-6.7 \%$ & $-6.4 \%$ \\
\hline 0.09 & NS & NS & NS & $-97.5 \%$ & $-71.0 \%$ & $-51.7 \%$ & $-39.7 \%$ & $-31.7 \%$ & $-26.1 \%$ & $-22.0 \%$ & $-18.8 \%$ & $-16.4 \%$ & $-14.5 \%$ & $-13.0 \%$ & $-11.7 \%$ & $-10.7 \%$ & $-9.9 \%$ & $-9.1 \%$ & $-8.5 \%$ & $-8.0 \%$ & $-7.6 \%$ & $-7.2 \%$ & $-6.9 \%$ & $-6.7 \%$ \\
\hline 0.11 & NS & NS & NS & NS & $-97.5 \%$ & $-71.0 \%$ & $-51.7 \%$ & $-39.7 \%$ & $-31.7 \%$ & $-26.1 \%$ & $-22.0 \%$ & $-18.8 \%$ & $-16.4 \%$ & $-14.5 \%$ & $-13.0 \%$ & $-11.7 \%$ & $-10.7 \%$ & $-9.9 \%$ & $-9.1 \%$ & $-8.5 \%$ & $-8.0 \%$ & $-7.6 \%$ & $-7.2 \%$ & $-6.9 \%$ \\
\hline 0.12 & NS & NS & NS & NS & NS & $-97.5 \%$ & $-71.0 \%$ & $-51.7 \%$ & $-39.7 \%$ & $-31.7 \%$ & $-26.1 \%$ & $-22.0 \%$ & $-18.8 \%$ & $-16.4 \%$ & $-14.5 \%$ & $-13.0 \%$ & $-11.7 \%$ & $-10.7 \%$ & $-9.9 \%$ & $-9.1 \%$ & $-8.5 \%$ & $-8.0 \%$ & $-7.6 \%$ & $-7.2 \%$ \\
\hline 0.14 & NS & NS & NS & NS & NS & NS & $-97.5 \%$ & $-71.0 \%$ & $-51.7 \%$ & $-39.7 \%$ & $-31.7 \%$ & $-26.1 \%$ & $-22.0 \%$ & $-18.8 \%$ & $-16.4 \%$ & $-14.5 \%$ & $-13.0 \%$ & $-11.7 \%$ & $-10.7 \%$ & $-9.9 \%$ & $-9.1 \%$ & $-8.5 \%$ & $-8.0 \%$ & $-7.6 \%$ \\
\hline 0.16 & NS & NS & NS & NS & NS & NS & NS & $-97.5 \%$ & $-71.0 \%$ & $-51.7 \%$ & $-39.7 \%$ & $-31.7 \%$ & $-26.1 \%$ & $-22.0 \%$ & $-18.8 \%$ & $-16.4 \%$ & $-14.5 \%$ & $-13.0 \%$ & $-11.7 \%$ & $-10.7 \%$ & $-9.9 \%$ & $-9.1 \%$ & $-8.5 \%$ & $-8.0 \%$ \\
\hline 0.19 & NS & NS & NS & NS & NS & NS & NS & NS & $-97.5 \%$ & $-71.0 \%$ & $-51.7 \%$ & $-39.7 \%$ & $-31.7 \%$ & $-26.1 \%$ & $-22.0 \%$ & $-18.8 \%$ & $-16.4 \%$ & $-14.5 \%$ & $-13.0 \%$ & $-11.7 \%$ & $-10.7 \%$ & $-9.9 \%$ & $-9.1 \%$ & $-8.5 \%$ \\
\hline 0.21 & NS & NS & NS & NS & NS & NS & NS & NS & NS & $-97.5 \%$ & $-71.0 \%$ & $-51.7 \%$ & $-39.7 \%$ & $-31.7 \%$ & $-26.1 \%$ & $-22.0 \%$ & $-18.8 \%$ & $-16.4 \%$ & $-14.5 \%$ & $-13.0 \%$ & $-11.7 \%$ & $-10.7 \%$ & $-9.9 \%$ & $-9.1 \%$ \\
\hline 0.25 & NS & NS & NS & NS & NS & NS & NS & NS & NS & NS & $-97.5 \%$ & $-71.0 \%$ & $-51.7 \%$ & $-39.7 \%$ & $-31.7 \%$ & $-26.1 \%$ & $-22.0 \%$ & $-18.8 \%$ & $-16.4 \%$ & $-14.5 \%$ & $-13.0 \%$ & $-11.7 \%$ & $-10.7 \%$ & $-9.9 \%$ \\
\hline 0.28 & NS & NS & NS & NS & NS & NS & NS & NS & NS & NS & NS & $-97.5 \%$ & $-71.0 \%$ & $-51.7 \%$ & $-39.7 \%$ & $-31.7 \%$ & $-26.1 \%$ & $-22.0 \%$ & $-18.8 \%$ & $-16.4 \%$ & $-14.5 \%$ & $-13.0 \%$ & $-11.7 \%$ & $-10.7 \%$ \\
\hline 0.33 & NS & NS & NS & NS & NS & NS & NS & NS & NS & NS & NS & NS & $-97.5 \%$ & $-71.0 \%$ & $-51.7 \%$ & $-39.7 \%$ & $-31.7 \%$ & $-26.1 \%$ & $-22.0 \%$ & $-18.8 \%$ & $-16.4 \%$ & $-14.5 \%$ & $-13.0 \%$ & $-11.7 \%$ \\
\hline 0.37 & NS & NS & NS & NS & NS & NS & NS & NS & NS & NS & NS & NS & NS & $-97.5 \%$ & $-71.0 \%$ & $-51.7 \%$ & $-39.7 \%$ & $-31.7 \%$ & $-26.1 \%$ & $-22.0 \%$ & $-18.8 \%$ & $-16.4 \%$ & $-14.5 \%$ & $-13.0 \%$ \\
\hline 0.43 & NS & NS & NS & NS & NS & NS & NS & NS & NS & NS & NS & NS & NS & NS & $-97.5 \%$ & $-71.0 \%$ & $-51.7 \%$ & $-39.7 \%$ & $-31.7 \%$ & $-26.1 \%$ & $-22.0 \%$ & $-18.8 \%$ & $-16.4 \%$ & $-14.5 \%$ \\
\hline 0.50 & NS & NS & NS & NS & NS & NS & NS & NS & NS & NS & NS & NS & NS & NS & NS & $-97.5 \%$ & $-71.0 \%$ & $-51.7 \%$ & $-39.7 \%$ & $-31.7 \%$ & $-26.1 \%$ & $-22.0 \%$ & $-18.8 \%$ & $-16.4 \%$ \\
\hline 0.57 & NS & NS & NS & NS & NS & NS & NS & NS & NS & NS & NS & NS & NS & NS & NS & NS & $-97.5 \%$ & $-71.0 \%$ & $-51.7 \%$ & $-39.7 \%$ & $-31.7 \%$ & $-26.1 \%$ & $-22.0 \%$ & $-18.8 \%$ \\
\hline 0.66 & NS & NS & NS & NS & NS & NS & NS & NS & NS & NS & NS & NS & NS & NS & NS & NS & NS & $-97.5 \%$ & $-71.0 \%$ & $-51.7 \%$ & $-39.7 \%$ & $-31.7 \%$ & $-26.1 \%$ & $-22.0 \%$ \\
\hline 0.75 & NS & NS & NS & NS & NS & NS & NS & NS & NS & NS & NS & NS & NS & NS & NS & NS & NS & NS & $-97.5 \%$ & $-71.0 \%$ & $-51.7 \%$ & $6-39.7 \%$ & $-31.7 \%$ & $-26.1 \%$ \\
\hline 0.87 & NS & NS & NS & NS & NS & NS & NS & NS & NS & NS & NS & NS & NS & NS & NS & NS & NS & NS & NS & $-97.5 \%$ & $-71.0 \%$ & $6-51.7 \%$ & $-39.7 \%$ & $-31.7 \%$ \\
\hline 1.00 & NS & NS & NS & NS & NS & NS & NS & NS & NS & NS & NS & NS & NS & NS & NS & NS & NS & NS & NS & NS & $-97.5 \%$ & $6-71.0 \%$ & $-51.7 \%$ & $-39.7 \%$ \\
\hline 1.15 & NS & NS & NS & NS & NS & NS & NS & NS & NS & NS & NS & NS & NS & NS & NS & NS & NS & NS & NS & NS & NS & $-97.5 \%$ & $-71.0 \%$ & $-51.7 \%$ \\
\hline 1.32 & NS & NS & NS & NS & NS & NS & NS & NS & NS & NS & NS & NS & NS & NS & NS & NS & NS & NS & NS & NS & NS & NS & $-97.5 \%$ & $-71.0 \%$ \\
\hline 1.52 & NS & NS & NS & NS & NS & NS & NS & NS & NS & NS & NS & NS & NS & NS & NS & NS & NS & NS & NS & NS & NS & NS & NS & $-97.5 \%$ \\
\hline 1.74 & NS & NS & NS & NS & NS & NS & NS & NS & NS & NS & NS & NS & NS & NS & NS & NS & NS & NS & NS & NS & NS & NS & NS & NS \\
\hline
\end{tabular}

Figure 4 Effect of $(A) 0.5 \%,(B) 1 \%,(C) 2 \%$, and $(D) 5 \%$ additional mortality on the percentage change in Population Persistence Index (PPI). Each cell in the matrix represents a population defined by its adult mortality rate $m$ and maximum recruitment rate $r_{1}$. Especially populations in which the mortality $m$ approaches the maximum recruitment $r_{1}$ are very sensitive to an increase in mortality. $N S=$ no survival (i.e. population cannot exist), red $=50-100 \%$, orange $=25-50 \%$, dark pink $=10-25$, medium pink $=5-10$, light pink $=2-5 \%$ and green $=0-2 \%$, blue = area of non-realistic parametrisation ("Darwinian demons") that combine a high adult survival (longevity) and a high recruitment (roughly based on Sæther and Bakke (2000)). 


\subsection{Impact of PBR on the Population Persistence Index}

The Potential Biological Removal (PBR) is often used to calculate how many individuals of a given population can be harvested without negatively affecting the population. Strong effects of harvesting, or additional mortality following wind turbine collision, on PPI are evident using the PBR (Figs. 5A and B). When the recovery factor Fr equals 1 , additional mortality according to the PBR results in an $87.5 \%$ reduction of the PPI. When $\mathrm{Fr}=0.5$ this reduction is $58 \%$ and when $\mathrm{Fr}=0.1$ the reduction of $\mathrm{PPI}$ is $15 \%$.

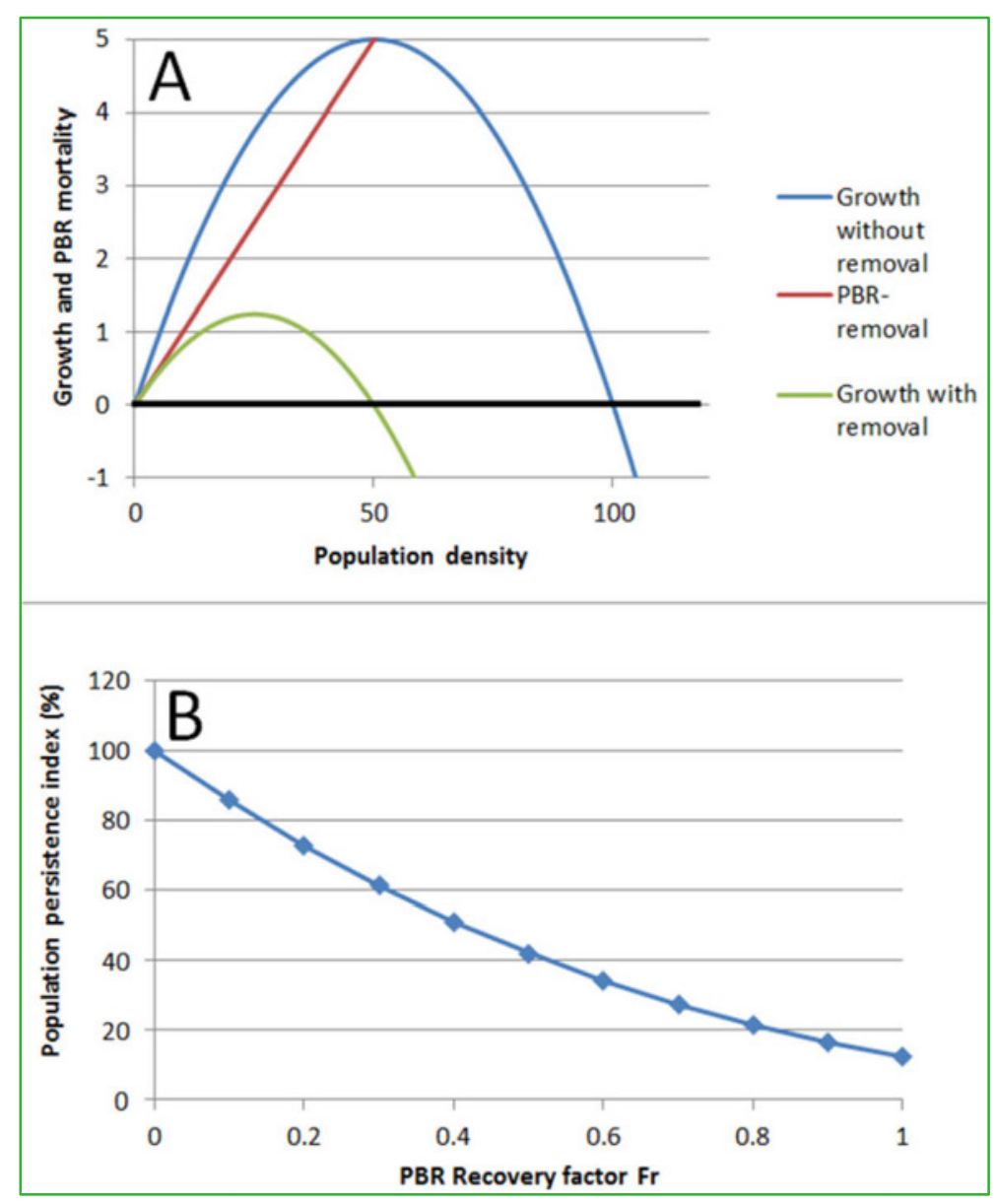

Figure 5 Effects of Potential Biological Removal (PBR) on the Population Persistence Index (PPI), the area under the parabolic curves in $A$. (A) Effects of $P B R$ (with recovery factor $(F r)=1$, red line) on the population (blue line) resulting in a population with a strongly reduced PPI (green line).

(B) Effect of the recovery factor Fr on the \% decrease of the PPI. Note that the proportional change in $P P I$ is independent of $r$ and $K$ and depends only on Fr.

\subsection{Effect of increased mortality on Common Tern and Marsh Harrier}

\section{Common Tern}

In the best available years for the Waddenzee-IJsselmeer population (2007, 2010, 2011), Common Terns produced 1.1 fledglings per pair of which $89.9 \%$ survived the post fledgling period and $68.5 \%$ survived the remainder of the year. Second year-survival was $64.6 \%$ and third-year survival was estimated at $88.5 \%$. The recruitment rate to adulthood $(r 1)$ can thus be estimated as:

$0.5 * 1.1 * 0.899 * 0.685 * 0.646 * 0.885=0.194(0.5$ factor reflects balanced sex ratio $)$ and in a continuous time model as $r 1=\ln (0.194+1)=0.177$. The adult mortality rate is $1-0.885=0.115$ and $-\ln (1-0.115)$ 
$=0.122$ in the continuous time model. Analogously, we can estimate the increased mortality rate mi after a hypothetical increase in wind turbine strikes as $-\ln \left(1-0.115^{*} 1.01\right)=0.1234$. The reduced recruitment $\mathrm{r} 1 \mathrm{i}$ in this situation is $0.5 * 1.1 *(1-0.101 * 1.01) *(1-0.315 * 1.01) *(1-0.354 * 1.01) *(1-$ $0.115 * 1.01)=0.1912$ and in a continuous time model $r 1 \mathrm{i}=\ln (0.1912+1)=0.175$.

We substitute these estimates in equation (6) to assess the proportional response of the Population Persistence Index (PPI) to increased mortality following a hypothetical increase of mortality due to wind turbine strike. Using these estimates for $\mathrm{r} 1$ and $\mathrm{m}$, a $1 \%$ increase in mortality (impacting recruitment and adult cohorts) resulted in a $15.1 \%$ loss of the PPI, increasing to a $61 \%$ decrease of PPI at a $5 \%$-increase of mortality (Table 1 ).

For the PBR of Common Tern the proportional change of the PPI is independent of $r, r 1$ and $m$ but depends only on the adjustment factor of population sensitivity (Fr). An Fr value of 0.5 results in a $58 \%$ reduction of the PPI compared to the population not exposed to additional mortality (Table 1 ).

\section{Marsh Harrier}

In the best available years $(1997,1998,1999)$ Marsh Harriers produced on average 2.9 fledglings per pair of which $66.4 \%$ survived the first year and $78.5 \%$ the second and third year. The recruitment on an annual basis is: $0.5 * 2.9 * 0.664 * 0.785 * 0.785=0.59$ and in a continuous time model $r 1=\ln (0.59+1)=0.464$. The adult mortality rate is $1-0.785=0.215$ and $-\ln (1-0.215)=0.242$ in a continuous time model. Then, the recruitment $\mathrm{r} 1 \mathrm{i}$ due to a mortality increase of $1 \%=0.5 * 2.9 *(1-$ $0.336 * 1.01) *(1-0.215 * 1.01) *(1-0.215 * 1.01)=0.587$ and in a continuous time model $\mathrm{r} 1 \mathrm{i}=\ln (0.587+1)=0.4619$. The $\mathrm{mi}$ is $-\ln (1-0.215 * 1.01)=0.2448$.

We substitute these estimates in equation (6) to assess the proportional response of the Population Persistence Index (PPI) to increased mortality following a hypothetical increase in wind turbine strikes. A $1 \%$ increase in mortality resulted in an $7.1 \%$ loss of the PPI, increasing to a $33 \%$ decrease of PPI at a $5 \%$ rise in mortality (Table 1 ).

Considering that the Marsh Harrier is a sensitive species we assume an Fr of 0.1 for the PBR, which results in a reduction of the PPI by $14 \%$ compared to the population not exposed to additional mortality (Table 1 ).

Table 1 The proportional change of the Population Persistence Index (PPI) following an increase in mortality in Dutch populations of Common Tern and Marsh Harrier. The response of the PPI to Potential Biological Removal (PBR) was obtained by varying the population sensitivity factor (or recovery factor, Fr). Note that the response to PBR is only determined by Fr and is not species specific.

\begin{tabular}{|c|c|c|}
\hline & Marsh Harrier & Common Tern \\
\hline \multicolumn{3}{|c|}{$\%$ mortality increase } \\
\hline $1 \%$ & -7.1 & -15.2 \\
\hline $2 \%$ & -14.0 & -28.9 \\
\hline \multicolumn{3}{|c|}{ PBR - Fr values } \\
\hline 0 & 0 & 0 \\
\hline 0.1 & -14.19 & -14.19 \\
\hline 0.2 & -27.12 & -27.12 \\
\hline 0.6 & -65.7 & -65.7 \\
\hline 0.7 & -72.57 & -72.57 \\
\hline 0.8 & -78.4 & -78.4 \\
\hline 0.9 & -83.3 & -83.3 \\
\hline 1 & -87.5 & -87.5 \\
\hline
\end{tabular}




\section{Discussion}

We show that the use of threshold standards, such as the $1 \%$ mortality norm and PBR, to evaluate the impact of additional mortality from wind turbine strike can strongly reduce the persistence perspectives of populations of sensitive bird species, i.e. those species for which maximum recruitment is not much higher than natural mortality. Rather than having a negligible effect, we found that a $1 \%$ increase in mortality rates of all post-fledging age classes from wind turbine strike leads to a c. $7 \%$ and $15 \%$ decrease in population persistence for Dutch populations of respectively Marsh Harrier and Common Tern. In situations where such additional mortality increased by $5 \%$ for both species, we estimated a $33 \%$ to $62 \%$ decrease, respectively, of their population persistence. We further show that long-lived species with low recruitment rates may be as vulnerable to a similar degree of additional mortality as short-lived species with high reproductive potential (cf. Fig. 4). This may seem counter-intuitive given the known vulnerability of even low collision rates of various longlived species (Crivelli et al. 1988, Hunt \& Hunt 2006). However, additional 1\% mortality levels are reached much sooner in species with high natural survival rates and low population size. What matters is the difference between maximum potential recruitment (at low density, when resources are not limiting) and natural mortality. A species with high recruitment may still be vulnerable if mortality is similarly high.

The newly introduced measure of population persistence, the Population Persistence Index or PPI, is determined by maximum population growth rate and the carrying capacity of a population. The PPI thus combines safety in numbers and safety by population growth rate, reflecting resilience to increased mortality such as caused by collisions with newly constructed wind turbines. The vulnerability of a population with a low PPI may be due to a low carrying capacity despite a high growth rate. The low carrying capacity and PPI then corresponds with the population's vulnerability to newly introduced mortality causes (e.g. wind turbines), demographic stochasticity and Allee effects (Schippers et al. 2011; Verboom et al. 2001). Similarly, a population with a high carrying capacity but a low growth rate (and therefore low resilience) may be equally vulnerable to extinction when subjected to large fluctuations. Conversely, a healthy population with a high PPI will be relatively stable with a low extinction probability. Even for healthy populations, however, a reduction of the PPI always undermines their persistence perspective or robustness (i.e. the "population viability") by reducing their buffer capacity, rendering them more vulnerable to stochastic or structural hazards.

We believe that our results should have far-reaching implications for the industry involved in the evaluation of wind turbine impact on bird populations in the Netherlands and in various other European countries, where the thresholds assessments evaluated here are currently the norm. When used in their current form, these assessments may grossly underestimate the actual impact of extra mortality of populations already under pressure from other anthropogenic causes, especially when cumulative mortality from multiple wind farms leads to additional mortality in excess of the $1 \%$ mortality norm. Importantly, we have not included in our assessment the additional impacts of disturbance, displacement, barrier effects, habitat change, and loss of feeding or breeding grounds during construction and operation on bird populations. These may be substantial and add to direct impact of mortality collisions (Drewitt \& Langston 2006, Schuster et al. 2015). This would make it more difficult to achieve the overall objectives under the Birds and Habitats Directives, which is to maintain and restore the populations of naturally occurring wild bird species present in the EU (ca. 500 species) at a level which will ensure their survival over the long term, maintaining them at a socalled 'favourable conservation status'. Our analysis adds to growing evidence that assessment thresholds offer only false security because they are rather arbitrary and embed the acceptance of some adverse impact on population size (Green et al. 2016).

The Potential Biological Removal is a measure often used as an alternative to the $1 \%$ mortality criterion. The starting point of the PBR is the maximum potential excess growth, which may not always be reached, especially not in declining populations, and can in practice only be determined at 
low population densities. Furthermore, the PBR method assumes density-dependence in mortality and reproduction, whereas knowledge about such dynamics is lacking for many species (Green et al. 2016). Uncertainties about the outcome of PBR applications also occur as a result of the use of a 'recovery factor' (Dillingham \& Fletcher 2008) which provides safety margins to PBR threshold estimates based upon expert judgement, but which lacks any empirical validation (Green et al. 2016). We show that the effect of PBR on the PPI response was only determined by the recovery factor Fr and was independent of the maximum recruitment $r 1$ and adult mortality $\mathrm{m}$. This means that the response of PPI following increased mortality from wind turbine collisions is entirely dependent on the estimation of Fr, which is a measure of the population's sensitivity to extinction. Presently, for sensitive populations $\mathrm{Fr}=0.1$ is often used while in more stable populations values near one are used (Wade 1998). Our results show that a PBR at $\mathrm{Fr}=1$ will cause an $87.5 \%$ decline in the PPI; meaning that the odds of population persistence will be strongly reduced. Perhaps surprisingly, even if the recovery factor is set at its lowest value $(\mathrm{Fr}=0.1)$, the proportional loss of population persistence amounts to $14 \%$ of the PPI without additional mortality. This implies that the PBR undermines the population persistence of populations suffering loss from wind turbine strike, although it may not lead to extinction. We conclude that the PBR method is a rather blunt instrument from a population conservation point of view.

Our results on the impact of additional mortality on Marsh Harrier and Common Tern populations are independent of the exact parameterization of respective population models. For most well-studied species, the average survival parameters and recruitment parameters such as average number of fledglings per pair can be estimated with a certain degree of accuracy. All parameters fluctuate over time due to internal population properties (such as population size, age structure, etc.) and external factors (weather, food availability etc.). We used the average of the three best years in terms of reproduction to estimate maximum recruitment and associated mortality, which is justifiable if we assume that intraspecific competition was at its lowest in these years. However, the adult survival rate estimated from field data is most likely to be lower than the intrinsic rate (i.e., the natural survival without humancaused mortality). For simplicity, we also assumed that $100 \%$ of the population bred at low density. Given this uncertainty and simplifying assumptions, we suggest not to focus on the exact quantitative outcome of this study, but on the general trends. We recommend that more research is conducted to better understand the recruitment and mortality dynamics of specific bird populations that show declining trends or populations with numbers below favourable reference values.

Given the likelihood of important impacts on population persistence of vulnerable species at additional mortality rates from wind turbine collisions close to, at, or slightly over $1 \%$ additional mortality, the importance of cumulative mortality from collisions at multiple wind farms becomes evident. Especially when we consider highly mobile or migratory species that encounter possibly multiple wind farms in their breeding area, but also multiple wind farms on their migration routes, the cumulative effects of mortality induced by these multiple wind farms may be important. An appropriate assessment should therefore take into account all accumulation of mortality in the populations' year-round range, a spatial scale reflecting the wide-ranging movements of many vulnerable, high collision-risk species (e.g. Bellebaum et al. 2013). Despite their importance to evaluate the true impact of wind turbines on relevant population levels, cumulative assessments are evidently seldom performed; because victim monitoring data are difficult to acquire at the relevant spatial scales and monitoring of mortality by authorities are seldom coordinated to encompass cumulative mortality at multiple sites (Broekmeyer \& Sanders 2013). In the juridical process of some countries (e.g. Netherlands), wind farm development projects that were completed several years back are excluded from any evaluation of cumulative impact. Consequently, the $1 \%$ mortality norm is often applied only to evaluate the effect of additional mortality on the conservation status of the species in the single area where the park is planned. When such additional mortality is lower than $1 \%$ of the natural mortality of a species, its impact is deemed negligible. This has repercussions for the way in which impact is estimated at the relevant, population level. For example, in one region in the Netherlands, the IJsselmeer-Waddenzee area, the cumulative estimated mortality impact of multiple wind farms on Common Tern and Marsh Harrier well exceeds the $1 \%$ mortality norms for breeding populations of these species, assuming that the casualties are birds of the local populations (cf. Annex 5). Our results indicate this may have implications for their population persistence well beyond the small or negligible effects that were estimated by single Appropriate Assessment procedures of the respective windfarms in the area. 


\section{$5 \quad$ Conclusions}

With the use of the $1 \%$ mortality norm and PBR methods, the impact of wind turbine collisions on populations is currently underestimated and the resulting impacts are likely to threaten the conservation status of already vulnerable species. Moreover, cumulative effects may be responsible for a much larger impact of wind parks combined than the estimated effects of single wind park projects, something that most impact assessment studies ignore. The response of the population persistence index PPI to a mortality increase is generally higher than the mortality increase itself, and much higher for vulnerable species. Any lowering of the population persistence index of a population reduces its buffer capacity to recover from any stochastic or structural hazard that lowers its population size, and thereby increases the risk of extinction. For populations that have high maximum recruitment rates and low natural mortality rates (e.g. goose populations in much of the Holarctic), that have a low PPI response, this risk is extremely small. However, other populations in which the natural mortality approaches the maximum recruitment are very sensitive to even a small increase in mortality. Developments that affect the mortality rates of these species, such as wind turbine development, should take such effects into consideration. Especially for these and other species already under pressure, more effort than what is currently the norm should be invested into minimizing the impact of wind farms on their populations. This includes an examination of cumulative mortality, flight behaviour and population models that evaluate the impact of even "incidental" additional mortality. In general the most suitable method of limiting negative impacts is to plan wind farms in areas where additional mortality of sensitive populations can be reduced to a minimum.

For populations that are declining, in which case recruitment < mortality, no safe additional mortality levels exist, as even a small increase in mortality takes the population further away from the favourable reference values. In these cases it is very important to estimate the maximum recruitment, i.e. the recruitment occurring at low population densities where density-dependent resource limitations do not play a role. With observed maximum recruitment lower than the natural mortality, the $1 \%$ mortality norm nor the PBR can be used without risking extinction of the populations in question. With maximum recruitment higher than, but close to natural mortality, the population is expected to eventually settle in a new, lower, equilibrium, and we showed that the impact of additional mortality on the population persistence is high under such conditions, leading to further decline below favourable reference values. Given such considerations, we conclude that both the $1 \%$ mortality norm and the PBR can only be used for thriving, resilient, large populations. In all cases where populations are below favourable reference values, when they are declining, and/or are considered fragile because recruitment in good years and mortality are not well balanced, the use of the $1 \%$ standard and/or the PBR method will seriously underestimate the impacts of additional mortality. 


\section{References}

Arnold, T.W. and Zink, R.M., 2011. Collision mortality has no discernible effect on population trends of North American birds. PLoS ONE, 6(9), p.e24708.

Barrios, L. and Rodriguez, A., 2004. Behavioural and environmental correlates of soaring-bird mortality at on-shore wind turbines. Journal of Applied Ecology, 41(1), pp.72-81.

Beissinger, S.R. and McCullough, D.R., 2002. Population Viability Analysis. University of Chicago Press.

Bellebaum, J., Korner-Nievergelt, F., Dürr, T. and Mammen, U., 2013. Wind turbine fatalities approach a level of concern in a raptor population. Journal for Nature Conservation, 21(6), pp.394-400.

Boyce, M.S., 1992. Population viability analysis. Annual Review of Ecology and Systematics, 23(1), pp.481-497

Brenninkmeijer, A., E. Klop. 2015. Aanvullende ecologische beoordeling windenergie Groningen. Effecten op Visdief en Noordse stern. A\&W-rapport 2120. Altenburg \& Wymenga ecologisch onderzoek, Feanwâlden.

Carrete, M., Sánchez-Zapata, J.A., Benítez, J.R., Lobón, M. and Donázar, J.A., 2009. Large scale riskassessment of wind-farms on population viability of a globally endangered long-lived raptor. Biological Conservation, 142(12), pp.2954-2961.

Caswell, H. Matrix Population Models. John Wiley \& Sons, Ltd, 2001.

Crivelli, A.J., Jerrentrup, H. and Mitchev, T., 1988. Electric Power Lines: A Cause of Mortality in Pelecanus crispus Bruch, a World Endangered Bird Species, in Porto-Lago, Greece. Colonial Waterbirds, pp.301-305.

COMMISSION OF THE EUROPEAN COMMUNITIES 1993. COM(93) 572 final Second report on the application of Directive No 79/409/EEC on the conservation of wild birds.

Courchamp, F., Clutton-Brock, T. and Grenfell, B., 1999. Inverse density-dependence and the Allee effect. Trends in ecology \& evolution, 14(10), pp.405-410.

Dahl, E.L., Bevanger, K., Nygård, T., Røskaft, E. and Stokke, B.G., 2012. Reduced breeding success in white-tailed eagles at Smøla windfarm, western Norway, is caused by mortality and displacement. Biological Conservation, 145(1), pp.79-85.

Dillingham, P.W. and Fletcher, D., 2008. Estimating the ability of birds to sustain additional humancaused mortalities using a simple decision rule and allometric relationships. Biological Conservation, 141(7), pp.1783-1792.

Drewitt, A.L. and Langston, R.H., 2008. Collision effects of wind-power generators and other obstacles on birds. Annals of the New York Academy of Sciences, 1134(1), pp.233-266.

Erickson, W.P., Johnson, G.D. and David Jr, P., 2005. A summary and comparison of bird mortality from anthropogenic causes with an emphasis on collisions.

European Union, 2011. EU Guidance on wind energy developments and Natura 2000. Publication Office of the European Union, Luxembourg.

Faanes, C.A., 1987. Bird behavior and mortality in relation to power lines in prairie habitats (No. TR-7). Fish and Wildlife Service, Washington DC.

Flather CH, Hayward GD, Beissinger SR, Stephens PA (2011) Minimum viable populations: Is there a 'magic number' for conservation practitioners? Trends in Ecology and Evolution 26: 307-316.

Gilroy, J.J. and Sutherland, W.J., 2007. Beyond ecological traps: perceptual errors and undervalued resources. Trends in Ecology \& Evolution, 22(7), pp.351-356.

Green, R.E., Langston, R.H., McCluskie, A., Sutherland, R. and Wilson, J.D., 2016. Lack of sound science in assessing wind farm impacts on seabirds. Journal of Applied Ecology, 53(6), pp.1635-1641.

Horswill, C., O’Brien, S.H. and Robinson, R.A., 2016. Density dependence and marine bird populations: are wind farm assessments precautionary? Journal of Applied Ecology.

Hunt, G. and Hunt, T., 2006. The trend of golden eagle territory occupancy in the vicinity of the Altamont Pass Wind Resource Area: 2005 survey. Unpublished report of the California energy Commission, PIeR energy-Related environmental Research, CeC-500-2006-056.

Katzner, T.E., Nelson, D.M., Braham, M.A., Doyle, J.M., Fernandez, N.B., Duerr, A.E., Bloom, P.H., Fitzpatrick, M.C., Miller, T.A., Culver, R.C. and Braswell, L., 2016. Golden Eagle fatalities and the continental-scale consequences of local wind-energy generation. Conservation Biology.

doi: $10.1111 /$ cobi. 12836 
Klem Jr, D., 1990. Collisions between birds and windows: mortality and prevention. Journal of Field Ornithology, pp.120-128.

Klem Jr, D., Keck, D.C., Marty, K.L., MILLER BALL, A.J., Niciu, E.E. and Platt, C.T., 2004. Effects of window angling, feeder placement, and scavengers on avian mortality at plate glass. The Wilson Bulletin, 116(1), pp.69-73.

Law, R. 1979 Optimal Life Histories under age-specific Predation. American Naturalist 114: 399-417.

Liley, D. and Sutherland, W.J., 2007. Predicting the population consequences of human disturbance for Ringed Plovers Charadrius hiaticula: a game theory approach. Ibis, 149(s1), pp.82-94.

Marques, A.T., Batalha, H., Rodrigues, S., Costa, H., Pereira, M.J.R., Fonseca, C., Mascarenhas, M. and Bernardino, J., 2014. Understanding bird collisions at wind farms: an updated review on the causes and possible mitigation strategies. Biological Conservation, 179, pp.40-52.

Martin, T.E., 1987. Food as a limit on breeding birds: a life-history perspective. Annual Review of Ecology and Systematics, pp.453-487.

Martínez-Abraín, A., Tavecchia, G., Regan, H.M., Jimenez, J., Surroca, M. and Oro, D., 2012. Effects of wind farms and food scarcity on a large scavenging bird species following an epidemic of bovine spongiform encephalopathy. Journal of Applied Ecology, 49(1), pp.109-117.

Matthysen, E., 1990. Behavioral and ecological correlates of territory quality in the Eurasian Nuthatch (Sitta europaea). The Auk, pp.86-95.

Nagelkerke, K.C., Verboom, J., van den Bosch, F. and Van De Wolfshaar, K., 2002. Time lags in metapopulation responses to landscape change. In Applying Landscape Ecology in Biological Conservation (pp. 330-354). Springer New York.

Niel, C., Lebreton, J.-D., 2005. Using demographic invariants to detect overharvested bird populations from incomplete data. Conservation Biology 19, 826-835

Newton, I., 1993. Predation and limitation of bird numbers. In Current Ornithology (pp. 143-198). Springer US.

Newton, I., 1998. Population Limitation in Birds. Academic press.

Rappole, J.H. and McDonald, M.V., 1994. Cause and effect in population declines of migratory birds. The Auk, pp.652-660.

Sæther, B.E. and Bakke, $\varnothing ., 2000$. Avian life history variation and contribution of demographic traits to the population growth rate. Ecology, 81(3), pp.642-653.

de Sateleer, N, 2013. The Appropriate Impact Assessment and Authorisation Requirements of Plans and Projects likely to have impacts on Natura 2000 sites. Environmental law Network International.

Schippers, P, E. W. M. Stienen, A. G. M. Schotman, R. P. H. Snep, and P. A. Slim. 2011. 'The consequences of being colonial: Allee effects in metapopulations of seabirds', Ecological Modelling, 222: 3061-70.

Schuster, E., Bulling, L. and Köppel, J., 2015. Consolidating the state of knowledge: A synoptical review of wind energy's wildlife effects. Environmental management, 56(2), pp.300-331.

Sinclair, A.R.E. and Pech, R.P., 1996. Density-dependence, stochasticity, compensation and predator regulation. Oikos, pp.164-173.

Smallwood, K.S. and Thelander, C., 2008. Bird mortality in the Altamont Pass wind resource area, California. The Journal of Wildlife Management, 72(1), pp.215-223.

Sovon 2016. https://www.sovon.nl/nl/soort/6150. Accessed 9 January 2017.

Tilman, D., May, R.M., Lehman, C.L. and Nowak, M.A., 1994. Habitat destruction and the extinction debt. Nature, 371, pp.65-66.

van der Jeugd, H.P., Ens B.J., Versluijs M., and Schekkerman H., 2014. Geïntegreerde monitoring van vogels van de Nederlandse Waddenzee. Vogeltrekstation rapport 2014-01. Vogeltrekstation, Wageningen, Sovon-rapport 2014/18, Sovon Vogelonderzoek Nederland, Nijmegen.

Traill LW, Bradshaw CJA, Brook BW (2007) Minimum viable population size: A meta-analysis of 30 years of published estimates. Biological Conservation 139: 159-166.

Verboom, J., R. Foppen, P. Chardon, P. Opdam, and P. Luttikhuizen. 2001. 'Introducing the key patch approach for habitat networks with persistent populations: an example for marshland birds', Biological Conservation, 100: 89-101.

Verhulst, P.F., 1977. A note on the law of population growth. In Mathematical Demography (pp. 333339). Springer Berlin Heidelberg.

Verschuuren, J. M., (2009). 1\% criterium geaccepteerd bij habitattoets windmolens Weerribben, No. 61, Apr 01, 2009. (Milieu \& recht; Vol. (36)6, No. p. 399-401).

Wade, P., 1998. Calculating limits to the allowable human caused mortality of cetaceans and pinnipeds. Mar. Mamm. Sci. 14, 1-37. 


\section{Annex 1}

To assess the Area $(\mathrm{A})$ between $\mathrm{r}$ and $\mathrm{m}$ we integrate (main tekst) equation 1 over $\mathrm{N}$ :

$$
A=\int r N\left(1-\frac{N}{K}\right) d N=\frac{r}{2} N^{2}-\frac{r}{3 K} N^{3}
$$

The PPI is the area of equation 1 between zero and carryingcapacity $\mathrm{K}$ :

$$
P P I=\frac{r K^{2}}{6}
$$

For the logistic growth equation (main text equation 2 ) including mortality and recruitment in which $r=r_{1}-m, r 1$ being the maximum annual recruitment, or the recruitment at low density when resources are not limiting, and $m$ being the annual mortality PPI is:

$$
P P I=\frac{\left(r_{1}-m\right) K^{2}}{6}
$$

The PPI as a result of an increase in mortality with a percentage $\mathrm{i}$ is then:

$$
P P I_{i}=\frac{\left(r_{1 i}-m_{i}\right) K_{i}^{2}}{6}
$$

In which $r_{1 i}=r_{1}(1-i)$ and $m_{i}=m(1+i)$

But $K_{i}$ should be calculated from $K^{\prime}$, the density where the recruitment is zero, because $\mathrm{K}^{\prime}$ does not change due to mortality increase:

$$
\begin{aligned}
K^{\prime} & =\frac{K}{\left(1-m / r_{1}\right)} \\
K_{i} & =K^{\prime}\left(1-\frac{m_{i}}{r_{1 i}}\right)=K \frac{\left(1-\frac{m_{i}}{r_{1 i}}\right)}{\left(1-\frac{m}{r_{1}}\right)}
\end{aligned}
$$

Now we can calculate the Response in PPI $\left(R_{p p i}\right)$, or the proportional change of PPI, to be:

$$
R_{p p i}=\frac{P P I_{i}}{P P I}-1
$$

Substituting equation 3 and 4 in equation 7 and using the $K_{i}$ from equation 6 we get for the PPI response function:

$$
R_{P P I}=\frac{\left(r_{1 i}-m_{i}\right)\left(1-\frac{m_{i}}{r_{1 i}}\right)^{2}}{\left(r_{1}-m\right)\left(1-\frac{m}{r_{1}}\right)^{2}}-1
$$




\section{Annex 2}

De Potential Biological Removal is defined as (Wade 1998):

$$
P B R=0.5 \cdot N \cdot r \cdot F_{r}
$$

In which $\mathrm{r}=$ relative growth rate, $\mathrm{N}=$ population size, $\mathrm{F}_{\mathrm{r}}=$ adjustment factor for population sensitivity (also termed a "recovery factor" (Wade 1998)).

When we subtract the PBR harvest from the logistic equation we get:

$$
\frac{d N}{d t}=r N\left(1-\frac{N}{K}\right)-0.5 N r F_{r}=r\left(1-0.5 F_{r}\right) N-\left(\frac{r}{K}\right) N^{2}
$$

This population reaches and equilibrium $(\mathrm{dN} / \mathrm{dt}=0) \mathrm{K}_{\mathrm{PBR}}$ at:

$$
K_{P B R}=K\left(1-0.5 F_{r}\right)
$$

Let $\mathrm{Q}=\left(1-0.5 \mathrm{~F}_{\mathrm{r}}\right)$ so $\mathrm{K}_{\mathrm{PBR}}=\mathrm{KQ}$

To get the area under de curve, we integrate equation 2 over $\mathrm{N}$ we get:

$$
\text { Area }=0.5 r Q N^{2}-\left(\frac{r}{3 K}\right) N^{3}
$$

$\mathrm{PPI}_{\mathrm{PBR}}$ is the Area under curve from $\mathrm{N}=0$ to $\mathrm{K}_{\mathrm{PBR}}$, in which $\mathrm{K}_{\mathrm{PBR}}=\mathrm{KQ}$ is the equilibrium size of a population so:

$$
P P I_{P B R}=0.5 r Q(K Q)^{2}-\frac{r}{3 K}(K Q)^{3}=\frac{r Q^{3} K^{2}}{6}
$$

The area equation of unexploited logistic growing curve was (Annex 1 equation 2):

$$
P P I_{u}=\frac{r K^{2}}{6}
$$

And the PPI response \% relative to the unexploited area ( $\left.\mathrm{RPI}_{\mathrm{PPI}}\right)$ combining equation 5 and 6 is:

$$
R_{P P I}=\frac{P P I_{P B R}}{P P I_{u}}=\frac{\frac{Q^{3} r K^{2}}{6}}{\frac{r K^{2}}{6}}=Q^{3}
$$

We have defined $\mathrm{Q}=\left(1-0.5 \mathrm{~F}_{\mathrm{r}}\right)$ so:

$$
R_{p p i}=Q^{3}=\left(1-0.5 F_{r}\right)^{3}
$$

Note that $\mathrm{R}_{\mathrm{ppi}}$, the proportional change in PPI, is independent of $\mathrm{r}$ and $\mathrm{K}$ and depends only on Fr. 


\section{Annex 3}

Annual survival of Marsh Harriers was analysed using live resightings and dead recoveries of 12.059 birds ringed as nestling between 1991 and 2016 and 74 birds ringed as 'adult' in the same period (due to low sample sizes, birds ringed in their as first and second calendar year were lumped with older birds in the 'adult' category; Table 1). Nestlings were ringed in all years in approximately equal numbers (mean 475, range 258-773 per year). Prior to analysis, the dataset was checked for errors and birds recovered before the ringing date were removed, some obviously incorrect ages and cases where the species reported was other than Marsh Harrier due to misreadings of ring numbers were adjusted or removed. Duplicate records were also removed. Nestlings were ringed on average when 24.4 days old $(S D=6.9$, range 7-41 days, $\mathrm{N}=2295$ nestlings). Mars harriers fledge when between 35 and 40 days old. Eight nestlings were recovered within 20 days after ringing at the ringing location. As these birds never fledged, they were removed from the dataset prior to analysis.

A total of 226 birds were recovered dead, while there were 65 live resightings. Most birds, nestlings and older birds alike, were ringed in June and July. Recoveries and resightings were more evenly distributed over the year, but with a peak during the summer months. Data were grouped into oneyear periods spanning May-April. Survival is therefore measured between breeding seasons.

Table 1 Ringing and re-encounter data of Dutch Marsh harriers ringed in 1991-2016 by month

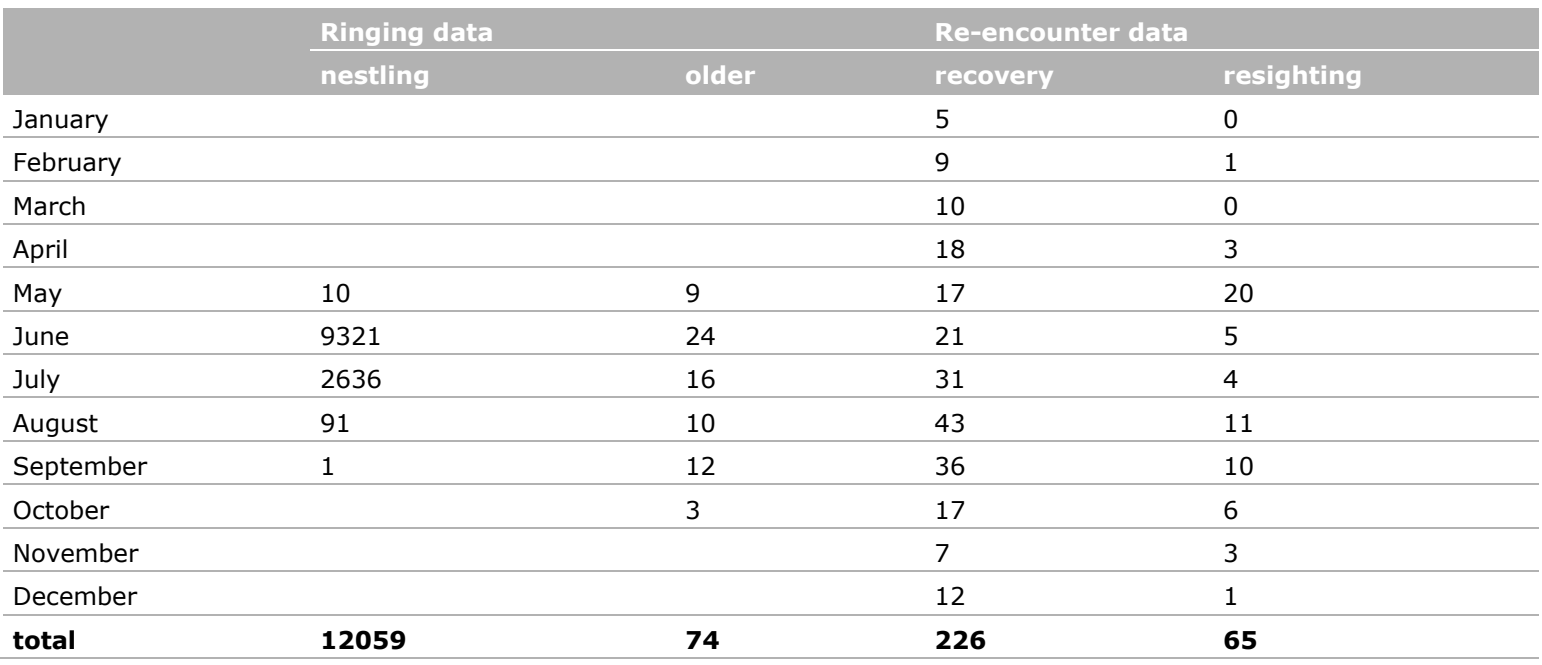

The recovery and resighting data were used in a combined analysis following Burnham (1993). In this type of MODEL, four types of parameters are estimated: $S$, the annual survival probability; $p$, the resighting probability (given that the bird is alive); $r$, the recovery probability of a dead ringed bird; and $F$, the fidelity probability, which is the probability that a surviving bird does not emigrate from the study area permanently. Program MARK (White \& Burnham 1999) was used for model fitting and parameter estimation. We fitted a number of biologically realistic models, where parameters depended on age at ringing (two groups g referring to nestlings and adults), age since ringing (reflecting true age in birds ringed as nestlings), and time (year). The effect of time on survival was modelled with year as a class variable, as a time trend, and by grouping individual years into five-year periods. Sex was not taken into account, as sex at ringing was not always recorded, and since re-encounters were rather scarce it was not feasible to add another factor to the model. Models were selected based on QAIC (Quasi-likelihood Akaike's Information Criterion), an information theoretic criterion corrected for the presence of overdispersion in the data set (Burnham \& Anderson 1998). Overdispersion was estimated as the variance inflation factor $\hat{c}$ through a bootstrap goodness-of-fit test (Cooch \& White 1999) and turned out to be modest at $\hat{c}=1 \cdot 13$. 
In a recovery-only analysis, age-dependent survival cannot be estimated in a dataset containing only birds ringed as nestlings when the age structure is applied to survival and recovery probabilities simultaneously (Cole et al. in press). This problem can be avoided by including birds ringed as adults, or by using an analysis including both dead recoveries and live resightings. Although both criteria were met in the present analysis, we carefully investigated the effect of a possible parameter redundancy in age-dependent models because dead recoveries greatly outnumber live resightings in our dataset and Marsh Harrier ringed as adults were rare and, hence, contributed little to the correct estimation of age-dependent survival.

\section{Results}

Starting from a model with full time dependence in all four parameters for both groups, we first started to model $F, r$ and $P$ respectively until a satisfactory model had been found for these 'nuisance parameters. This resulted in a simple model with age by group interactions for $F$ and $r$ and no reduction for $\mathrm{P}$ (Table 2 ). We then modelled survival by first introducing two age classes spanning first year survival and all subsequent survival values for both groups. Due to considerable heterogeneity in Survival in the adult group it was difficult to simplify the parameter structure for survival in this group. It was therefore not possible to test the biologically meaningful model where survival in the second age class for the juvenile group equalled survival in the adult group.

For the juvenile group, survival increased over time in both age classes. Some of the models including a time trend on survival did perform better than models with year-specific survival, but these models tended to overestimate the time trend on survival with survival increasing from very low to very high values over the study period, which did not seem realistic. Models where time was broken down into five periods of five years for the juvenile group performed best. In these models, survival increased more gradually over time in both age classes. A model with this structure and including three instead of two age classes performed slightly poorer. Since we wanted to avoid models where $S$ and $r$ were potentially confounded because of a similar age structure we again modelled $r$ leaving the final parameter structure for survival intact. Models with only a group effect on $r$ performed best. To investigate whether the increase in survival was not caused by a decrease in $r$ we also ran models that had the same five year periods on $r$. These models performed slightly poorer but did result in a slight decrease in $r$ over time and a lessening of the time effect on survival, although it was still present. However, in these models, the reporting rate in the last time period had to be fixed at a value similar to the previous period since it was not estimable. This model performed slightly better than models with a simple group effect on $r$. Finally, we simplified the structure for $F$ further letting $F$ only be different for birds ringed as juveniles in their first year, thereby testing the hypothesis that juveniles dispersed but older birds remained faithful to their site of firs capture.

Since all the above variants were quite similar in performance, we derived our final parameter estimates from model averaging. This resulted in survival slowly increasing from 0.48 to 0.78 in the first year of life, and from 0.59 to 0.90 in older birds. The increase in survival was most pronounced between the first and second time period (Figure 1 and Table 3). 


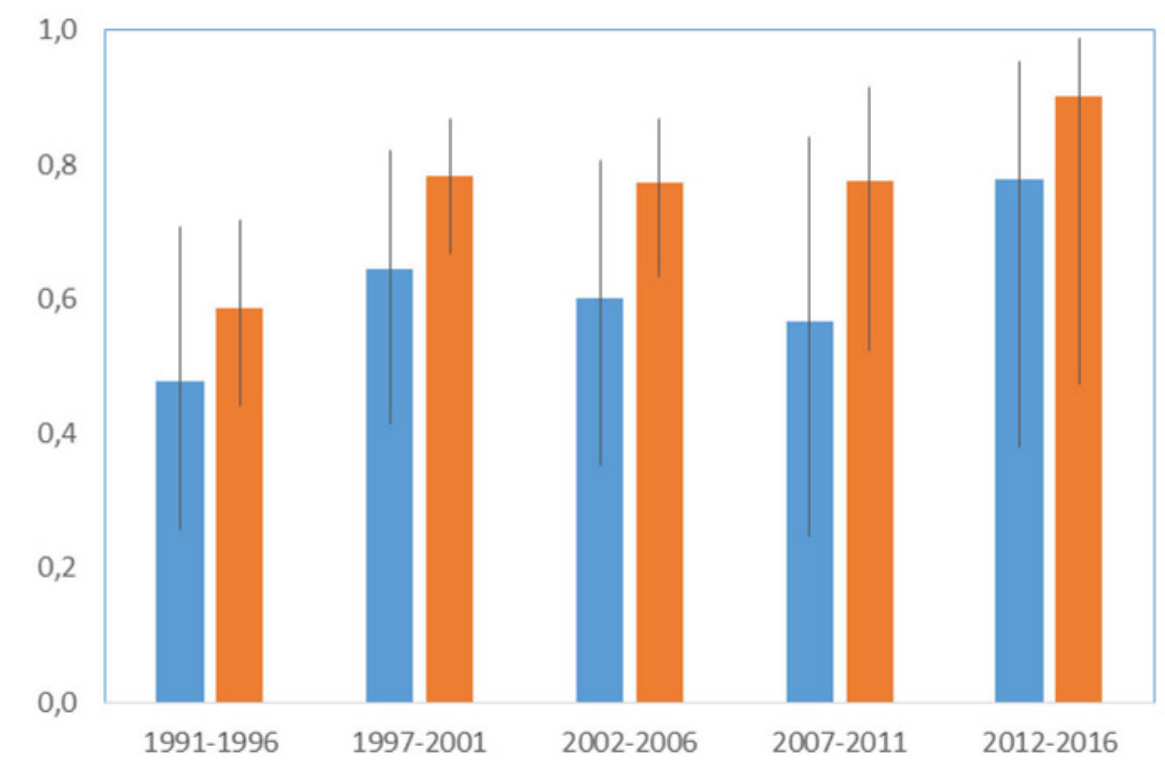

Figure 1 Annual survival ( $\pm 95 \% C I$ ) of juvenile and adult Marsh Harriers.

Table 3 Parameter estimates (only S; $P, r$ and $F$ will be included later)

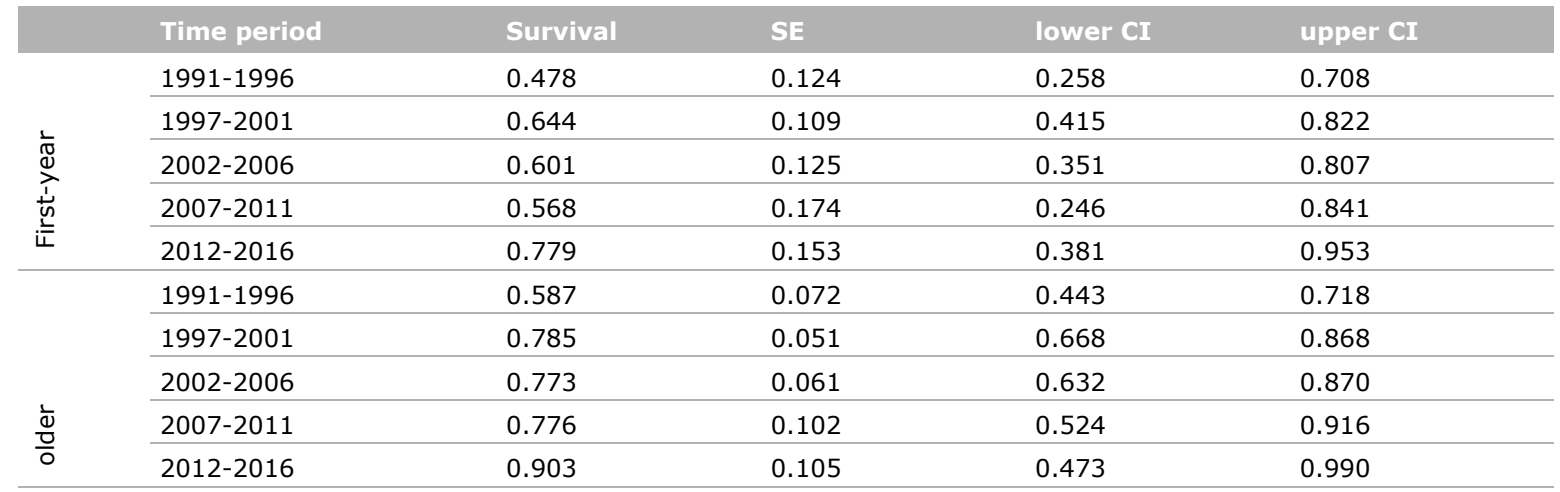


Table 2 Modelling results for Marsh Harrier survival rates

\begin{tabular}{|c|c|c|c|c|c|c|c|}
\hline Model & QAICC & $\triangle$ QAICC & AICc Weight & Model Likelihood & N. $\mathbf{P}$ & QDev & Remark \\
\hline$\{$ Phi(g1-a2*T5.g2-t).P(g*t).r(g-T5.g2-.).F(g*a2)\}last $r$ fixed $\}$ & 3265.116 & 0.000 & 0.387 & 1.000 & 31 & 300.893 & Best model: 5 time groups for $r$ (fixed) \\
\hline$\{$ Phi $(g 1-a 2 * T 5 \cdot g 2-t) \cdot P(g * t) \cdot r(g) \cdot F(g * a 2)\}$ & 3267.021 & 1.904 & 0.149 & 0.386 & 28 & 308.827 & 5 time groups on $\mathrm{S}$ \\
\hline$\{\mathrm{Phi}(\mathrm{g} 1-\mathrm{a} 2 * \mathrm{~T} 5 . \mathrm{g} 2-\mathrm{t}) \cdot \mathrm{P}(\mathrm{g} * \mathrm{t}) \cdot \mathrm{r}(\mathrm{g}) \cdot \mathrm{F}(\mathrm{g} 1-\mathrm{a} 2 . \mathrm{g} 2)\}$. & 3267.342 & 2.226 & 0.127 & 0.329 & 28 & 309.148 & No age effect on $\mathrm{F}$ in adult group \\
\hline$\{$ Phi(g1-a2*T5.g2-t).P(g*t).r(T5).F(g*a2)\} & 3267.956 & 2.840 & 0.094 & 0.242 & 31 & 303.733 & 5 time groups for $r$ \\
\hline$\{\mathrm{Phi}(\mathrm{g} 1-\mathrm{a} 2 * \mathrm{~T} 5 . \mathrm{g} 2-\mathrm{t}) \cdot \mathrm{P}(\mathrm{g} * \mathrm{t}) \cdot \mathrm{r}(\mathrm{g} * \mathrm{~T} 5) \cdot \mathrm{F}(\mathrm{g} * \mathrm{a} 2)\}$ & 3268.832 & 3.716 & 0.060 & 0.156 & 34 & 298.576 & 5 time groups for $r$ in both groups \\
\hline$\{\mathrm{Phi}(\mathrm{g} 1-\mathrm{a} 3 * \mathrm{~T} 5 \cdot \mathrm{g} 2-\mathrm{t}) \cdot \mathrm{P}(\mathrm{g} * \mathrm{t}) \cdot \mathrm{r}(\mathrm{g}) \cdot \mathrm{F}(\mathrm{g} * \mathrm{a} 2)\}$ & 3269.194 & 4.077 & 0.050 & 0.130 & 33 & 300.949 & 3 age classes instead of 2 \\
\hline$\{\mathrm{Phi}(\mathrm{g} *$ Ttrend.a2*Ttrend.g*a2).P(g*t).r(g*a2). $\mathrm{F}(\mathrm{g} * \mathrm{a} 2)\}$ & 3272.680 & 7.563 & 0.009 & 0.023 & 25 & 320.513 & Time trend on $\mathrm{S} ; \mathrm{r}: \mathrm{g} * \mathrm{a}$ \\
\hline$\{\mathrm{Phi}(\mathrm{g} 1-\mathrm{a} 2 * T 5 . g 2-\mathrm{t}) \cdot \mathrm{P}(\mathrm{g} * \mathrm{t}) \cdot \mathrm{r}(\mathrm{g} * \mathrm{a} 2) \cdot \mathrm{F}(\mathrm{g} * \mathrm{a} 2)\}$ & 3272.771 & 7.655 & 0.008 & 0.022 & 30 & 310.558 & Group by age interaction for $r$ \\
\hline$\{\mathrm{Phi}(\mathrm{g} 1-\mathrm{a} 2 * \mathrm{~T} 5 . \mathrm{g} 2-\mathrm{t}) \cdot \mathrm{P}(\mathrm{g} * \mathrm{t}) \cdot \mathrm{r}(\mathrm{g} * \mathrm{a} 2) \cdot \mathrm{F}(\mathrm{g} 1-\mathrm{a} 2 . \mathrm{g} 2)\}$. & 3274.262 & 9.146 & 0.004 & 0.010 & 30 & 312.049 & No age effect on $F$ in adult group; $r$ : $g^{*} a$ \\
\hline$\left\{\mathrm{Phi}\left(\mathrm{g} 1-\mathrm{a} 3^{*} \mathrm{~T} 5 . \mathrm{g} 2-\mathrm{t}\right) \cdot \mathrm{P}\left(\mathrm{g}^{*} \mathrm{t}\right) \cdot \mathrm{r}\left(\mathrm{g}^{*} \mathrm{a} 2\right) \cdot \mathrm{F}\left(\mathrm{g}^{*} \mathrm{a} 2\right)\right\}$ & 3276.512 & 11.395 & 0.001 & 0.003 & 36 & 3.276 .512 & 3 age classes instead of $2 ; r: g * a$ \\
\hline$\{$ Phi(g1-a2*T5.g2-T5).P(g*t).r(g).F(g*a2)\} & 3278.660 & 13.544 & 0.000 & 0.001 & 27 & 322.476 & 5 time groups for $\mathrm{S}$ in adult group \\
\hline$\{$ Phi(g1-a2*T5.g2-t).P(g1-t.g2-2).r(g).F(g*a2)\} & 3297.060 & 31.943 & 0.000 & 0.000 & 27 & 340.875 & Only $2 \mathrm{P}$ values for adult group \\
\hline$\{\mathrm{Phi}(\mathrm{g} 1-\mathrm{a} 2 * \mathrm{~T} 5 . \mathrm{g} 2-\mathrm{t}) \cdot \mathrm{P}(\mathrm{g} * \mathrm{t}) \cdot \mathrm{r}(\mathrm{g}-\mathrm{T} 5 \cdot \mathrm{g} 2-\cdot) \cdot \mathrm{F}(\mathrm{g} * \mathrm{a} 2)\}$ & 3702.051 & 436.935 & 0.000 & 0.000 & 37 & 385.108 & 5 time groups for $r$ in juvenile group \\
\hline \multicolumn{8}{|l|}{ Final model for P.r. F: } \\
\hline$\{\mathrm{Phi}(\mathrm{g} * \mathrm{t}) \cdot \mathrm{P}(\mathrm{g} * \mathrm{t}) \cdot \mathrm{r}(\mathrm{g} * \mathrm{a} 2) \cdot \mathrm{F}(\mathrm{g} * \mathrm{a} 2)\}$ & 3280.511 & 15.395 & 0.000 & 0.001 & 46 & 286.095 & \\
\hline \multicolumn{8}{|l|}{ starting model } \\
\hline$\{\mathrm{Phi}(\mathrm{g} * \mathrm{t}) \cdot \mathrm{P}(\mathrm{g} * \mathrm{t}) \cdot \mathrm{r}(\mathrm{g} * \mathrm{t}) \cdot \mathrm{F}(\mathrm{g} * \mathrm{t})\}$ & 3290.954 & 25.838 & 0.000 & 0.000 & 63 & 262.229 & \\
\hline
\end{tabular}




\section{Annex 4}

Breeding success of Marsh Harrier in the Netherlands was based on data managed by the Dutch Raptor Working Group (R.G. Bijlsma. unpublished). Data on nest success was limited to those nests which were followed from beginning to end of the breeding cycle. in order to limit a potential bias of overrepresentation of successful pairs. Nest data were available for different parts of the country. notably Zeeland and Friesland. with other important contributions from Wieringen.

\section{Results}

Data of 1914 nests were available to estimate nest success (Table 1 ). The best years in terms of nest success were 1997. 1998 and 1999. with reproductive output varying between 2.7 and 3.2 nestlings per nest. During the period a significant decline in nest success was evident $\left(F_{1.17}=16.6\right.$. $p<0.001$; Fig. 1).

Table $1 \quad$ Number of fledglings produced by Dutch Marsh Harriers between 1997 and 2015.

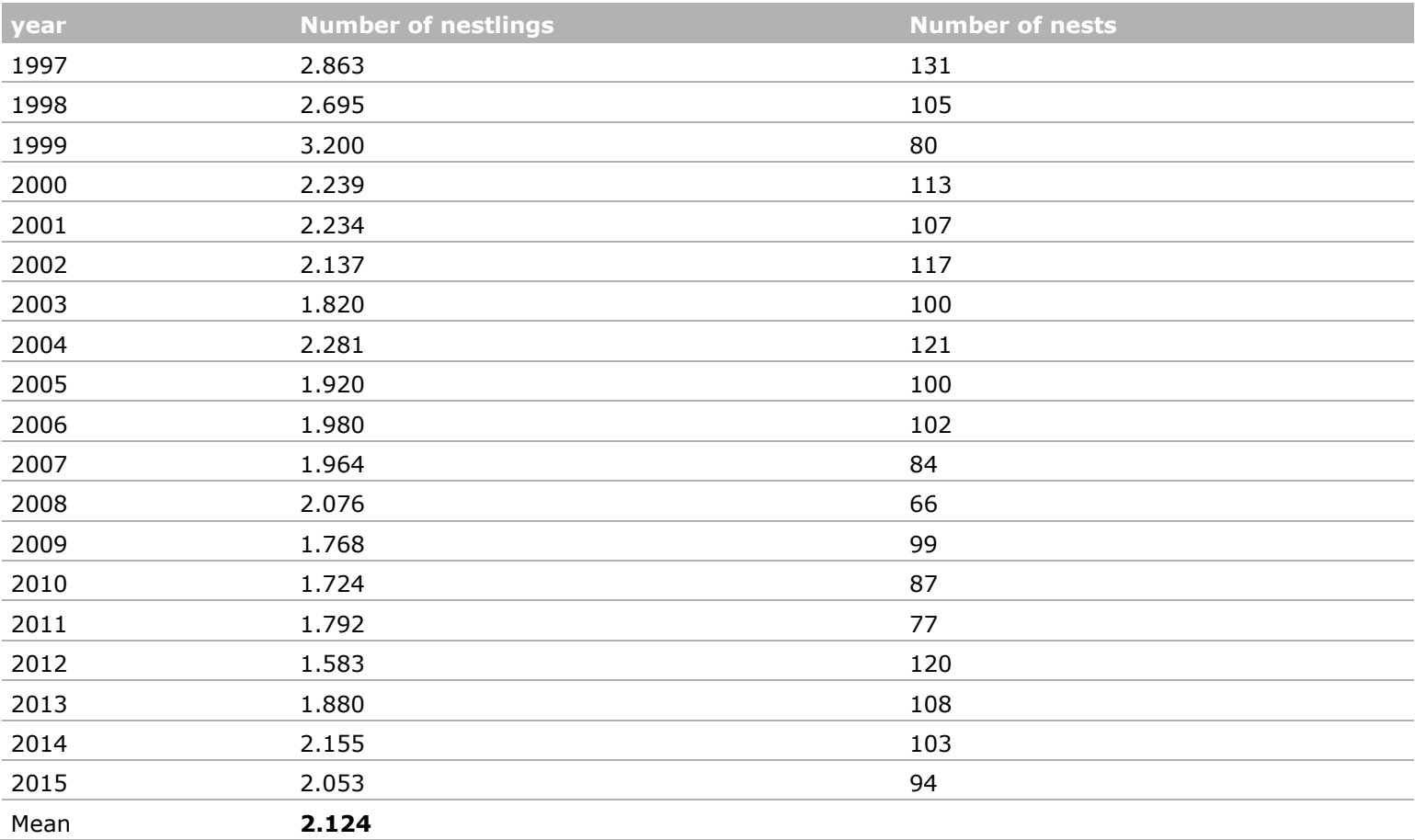




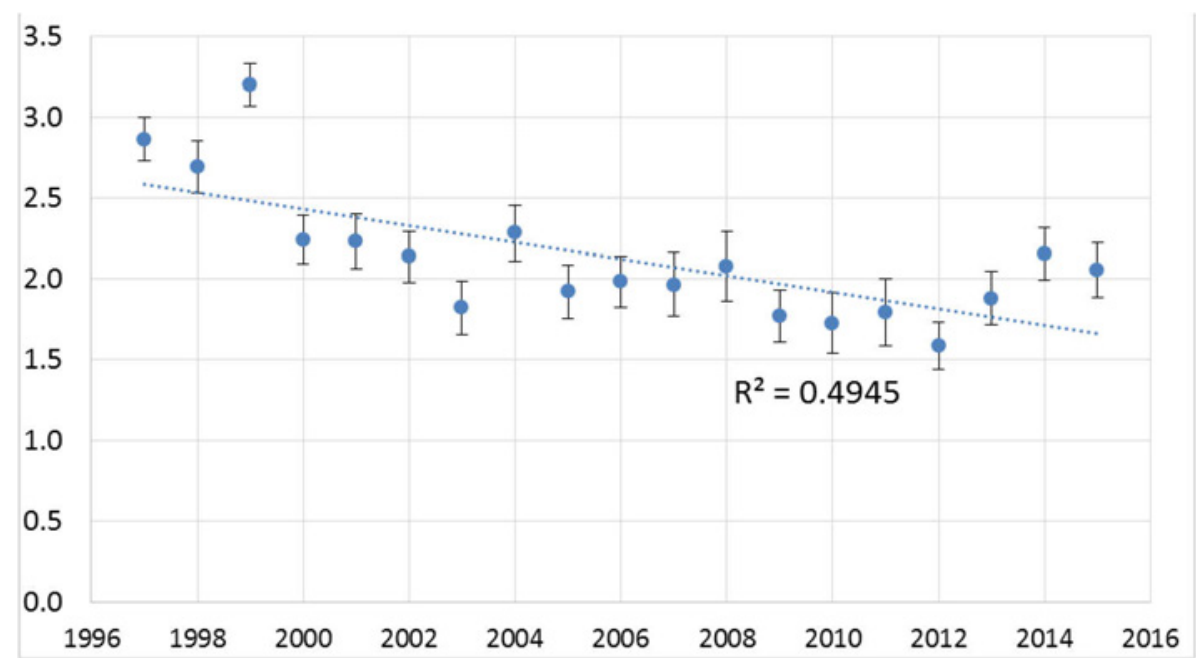

Figure $1 \quad$ Nest success ( \pm SE) for Dutch Marsh Harriers between 1997 and 2015. 


\section{Annex 5}

Cumulative mortality from windturbine collision in a population of Common Tern and Marsh Harrier in the Netherlands.

To evaluate the impact of cumulative mortality on the meta-populations of species modelled here. Common Tern and Marsh Harrier. the predicted number of victims from flux models or the (corrected) number based on monitoring of victims is used.

The Common Tern breeding population of Waddenzee and IJsselmeer is estimated at 7.630 pairs. The $1 \%$ norm then is: $0.01 * 0.10$ (adult mortality per year)*7630*3 (for every pair one floater; Brenninkmeyer \& Klop 2015) = 23 birds. The actual predicted additional mortality is 32 to 67 individuals in the entire breeding area (Table 1). by wind turbines only. i.e. a cumulative impact of up to c. $3 \%$ of the breeding population.

We also cumulated predicted mortality for the Marsh Harrier. The population of Waddenzee and IJsselmeer together is currently estimated at 52 pairs (Sovon 2016). The $1 \%$ mortality norm is $0.01 * 0.21 * 52 * 3=0.33$. i.e. one bird lost every three years. The estimated cumulative mortality at present for the Waddenzee-IJsselmeer area is 12-23 individuals per year (Table 2). It is unknown whether these victims are local breeding birds or migrants.

Table 1 Estimated number of victims of Common Tern per year in the meta-population IJsselmeer and Waddenzee. The minimum and maximum number of casualties per year are indicated. based on monitoring of victims (corrected for carcass detectability and scavenging) or flux collision models. Nbw = Nature Conservation Law; Ffw = Flora and Fauna Act.

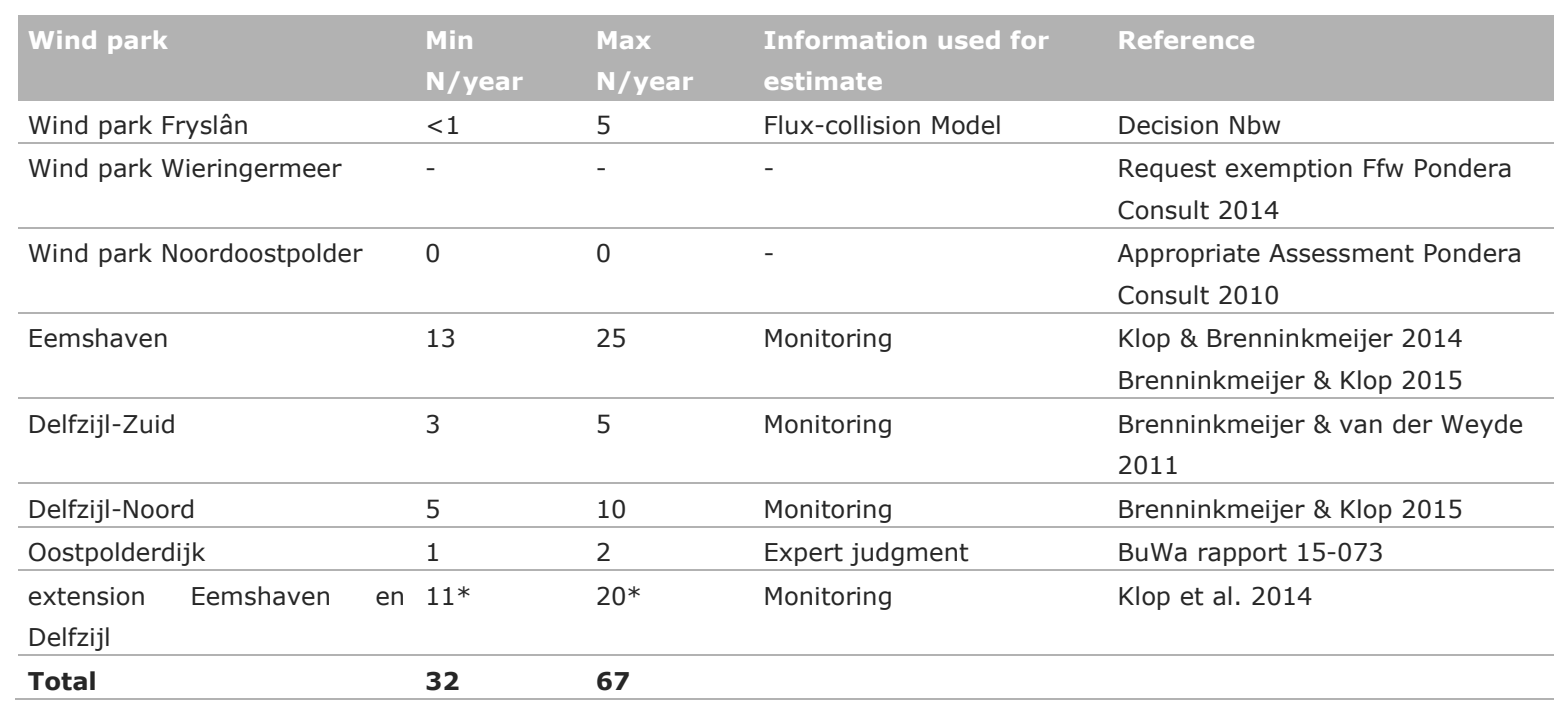

* with 95\% interval. 7.5 MW turbines and correction according to Loss et al. (2013). 
Table 2 Estimated number of victims of Marsh Harrier per year in the meta-population IJsselmeer and Waddenzee. The minimum and maximum number of casualties per year are indicated. based on monitoring of victims (corrected for carcass detectability and scavenging) or flux collision models. Nbw = Nature Conservation Law; Ffw = Flora and Fauna Act.

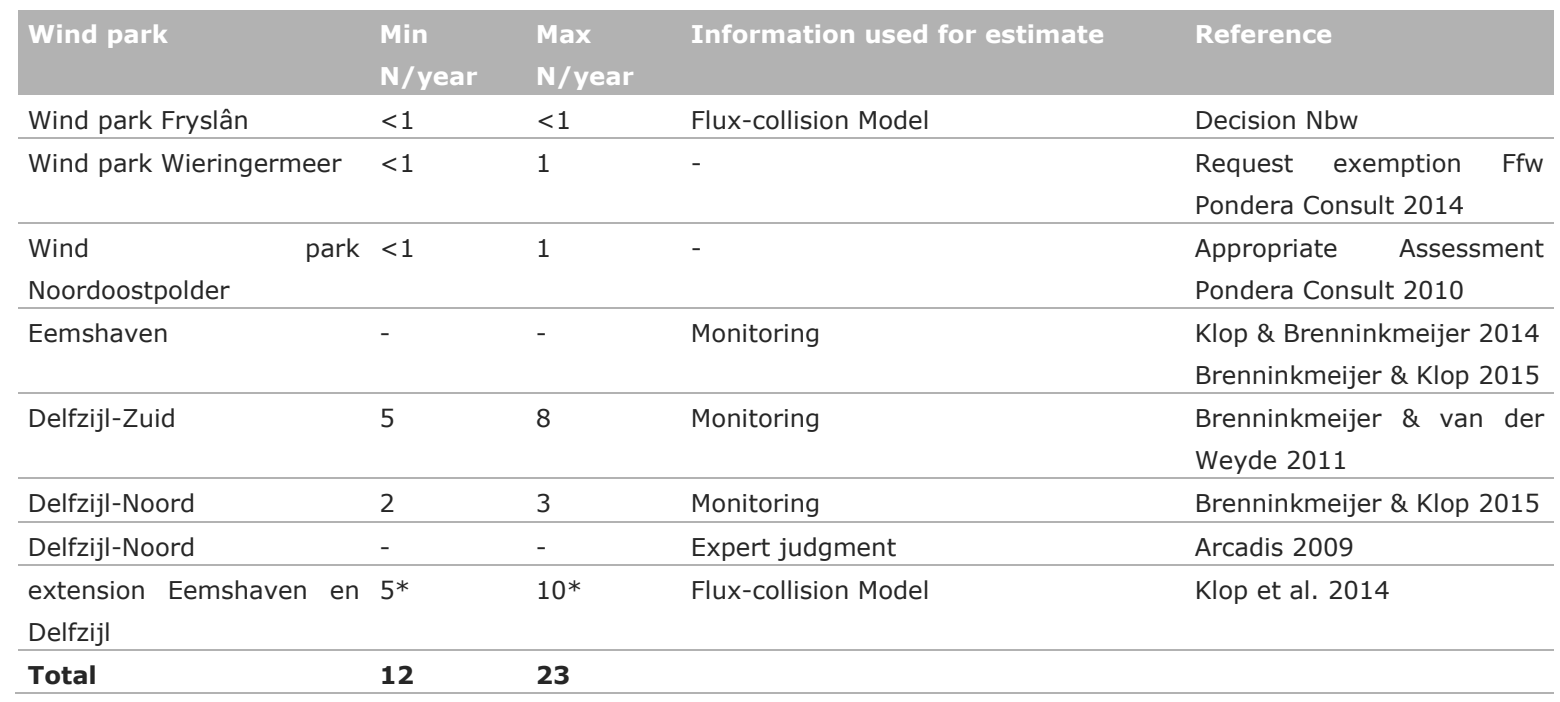

* with $95 \%$ interval. 7.5 MW turbines and correction according to Loss et al. (2013). 
Wageningen Environmental Research P.O. Box 47

6700 AA Wageningen

The Netherlands

T +31 (0)317480700

www.wur.nl/environmental-research

Wageningen Environmental Research Report 2788

ISSN 1566-7197
The mission of Wageningen University and Research is "To explore the potential of nature to improve the quality of life". Under the banner Wageningen University \& Research, Wageningen University and the specialised research institutes of the Wageningen Research Foundation have joined forces in contributing to finding solutions to important questions in the domain of healthy food and living environment. With its roughly 30 branches, 5,000 employees and 10,000 students, Wageningen University \& Research is one of the leading organisations in its domain. The unique Wageningen approach lies in its integrated approach to issues and the collaboration between different disciplines.

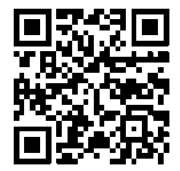




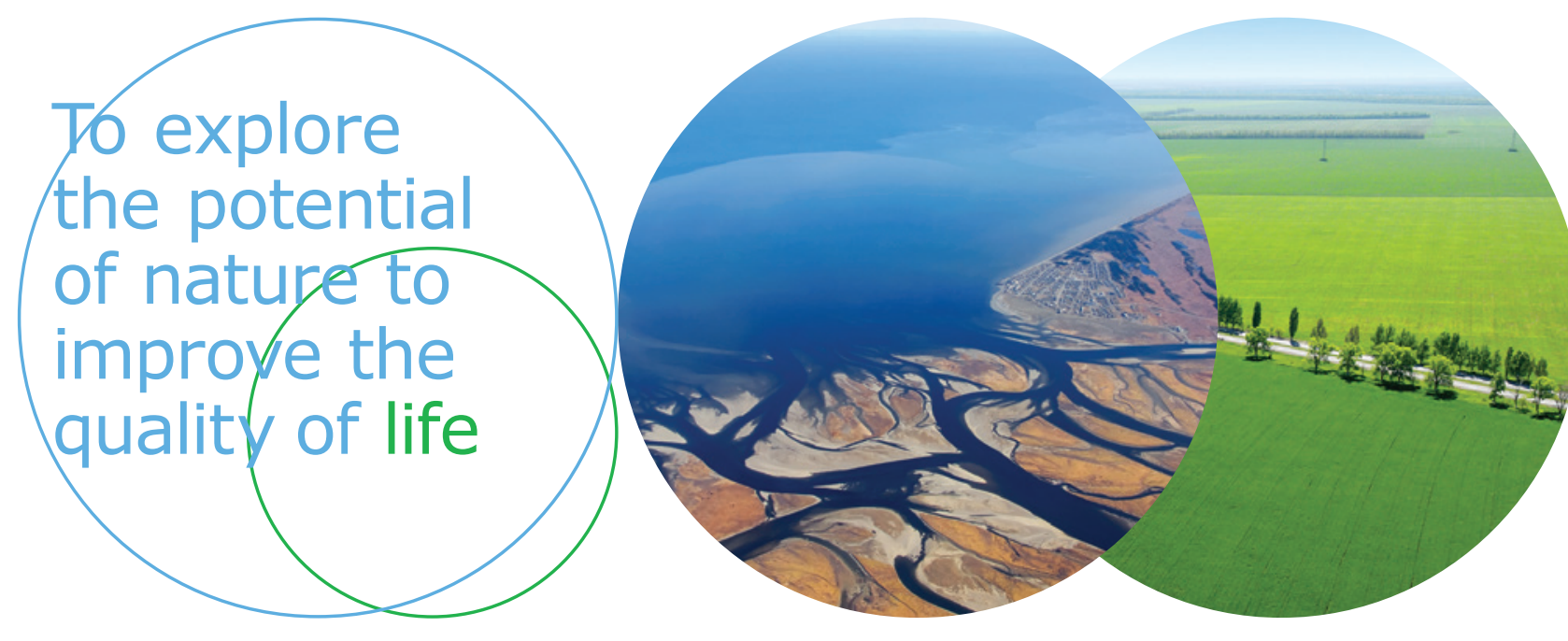

Wageningen Environmental Research P.O. Box 47

$6700 \mathrm{AB}$ Wageningen

The Netherlands

$\mathrm{T}+31(0) 317480700$

www.wur.eu/environmental-research

Report 2788

ISSN 1566-7197
The mission of Wageningen University and Research is "To explore the potential of nature to improve the quality of life". Under the banner Wageningen University \& Research, Wageningen University and the specialised research institutes of the Wageningen Research Foundation have joined forces in contributing to finding solutions to important questions in the domain of healthy food and living environment. With its roughly 30 branches, 5,000 employees and 10,000 students, Wageningen University \& Research is one of the leading organisations in its domain. The unique Wageningen approach lies in its integrated approach to issues and the collaboration between different disciplines. 